\title{
Article
}

\section{Exploring syntactic variation by means of "Language Production Experiments": Methods from and analyses on German in Austria}

\author{
Alexandra N. Lenz, Ludwig Maximilian Breuer, Matthias Fingerhuth, Anja Wittibschlager and Melanie E.-H. Seltmann \\ University of Vienna, Vienna, Austria
}

\begin{abstract}
This article presents computer supported "language production experiments" (LPEs) as a method for the investigation of syntactic variation. It describes the setup for the investigation of numerous syntactic phenomena and provides a sample study of the German GET passive across Austria. It also suggests that LPEs offer possibilities for the targeted investigation of linguistic variation in various ways. They may be used to explore speakers' individual linguistic repertoires and an according corpus setup can be used to examine e.g., interspeaker patterns of variation. LPEs also enable researchers to investigate which linguistic factors control or influence syntactic variation.
\end{abstract}

Keywords: syntax; variation; language production; experiments; GET passive; German in Austria

(Received 16 August 2018; accepted 2 February 2019)

\section{Content and goals}

While variationist linguistics has focused primarily on phonetics/ phonology since its inception, variationist research is slowly but increasingly starting to focus on syntactic variation. This research requires modifications and expansions of theoretical and methodological approaches of variationist linguistics (cf. Cheshire, 2005; Labov, 1978; Lavandera, 1978). This contribution primarily aims to provide a methodological enrichment of the discussion by adding an experimental approach to the previously predominant empirical approaches. Additionally, the syntactic "language production experiments" (cf. Section 3) attempt to seize a "syntactic variable" in an empirical manner.

Over the years, a broad spectrum of innovative projects on the variation of syntax has emerged, focusing particularly on the variation of dialect syntax. ${ }^{1}$ This research has broadened the empirical basis of modern linguistics and has shown that syntactic variation provides valuable insights into various linguistic disciplines. Regarding the survey methods, many of these projects use oral questionnaires, in which speakers are required to make judgements about grammaticality, acceptability and preference of syntactic variants. Research rarely relies upon "uncontrolled" conversational data, as this can be problematic when regarding syntactic variation (particularly when concerning quantity). This article presents an alternative and effective research method that offers solutions to the quantitative and qualitative problems of many other methodological approaches. This approach consists of computer supported

Author for correspondence: Alexandra N. Lenz, Email: alexandra.lenz@univie.ac.at Cite this article: Lenz AN, Breuer LM, Fingerhuth $M$, Wittibschlager $A$, and Seltmann MEH. (2019) Exploring syntactic variation by means of "Language Production Experiments": Methods from and analyses on German in Austria. Journal of Linguistic Geography 7: 63-81, https://doi.org/10.1017/jlg.2019.7 "language production experiments" (LPEs), which aim to evoke syntactic constructions and uncover the linguistic, as well as sociolinguistic, factors that control or influence variation. ${ }^{2}$

Our paper attempts to illustrate the potential and the limitations of LPEs when eliciting data on syntactic variation within a large-scale project, namely project part 03 "Between dialects and standard varieties: Speech repertoires and varietal spectra" of the Special Research Programme (Spezialforschungsbereich SFB) "German in Austria. Variation-Contact-Perception" (subsequently referred to as "SFB DiÖ" (Spezialforschungsbereich 'Deutsch in Österreich')). ${ }^{3}$ In the context of the SFB DiÖ, the LPEs are used to elicit language data from the (more or less dialectal) non-standard and the (more or less) standard spectrum of individuals' German language repertoires. The experiments facilitate the systematic investigation of syntactic variation, regarding the inter-individual variation across speakers in various regions of Austria, as well as the intra-individual variation on the "vertically" conceptualized "dialect-standard-axis" (cf. Auer, 2005) within one and the same speaker. As well as taking a methodological focus, this article presents comprehensive linguistic and sociolinguistic analyses of one selected syntactic phenomenon (the so called "GET passive" in German). The contribution is structured as follows: In the overview section (Section 2), the current state of areal-linguistic research into the syntactic level, with a focus on Europe and the German-speaking area, is summarized. Section 3 focuses on methodological aspects of the LPEs used in the SFB DiÖ project. Section 4 provides an exemplary analysis of one selected linguistic phenomenon to illustrate the productivity and validity of LPEs for the analysis of syntactic variation. The article closes with a summary in Section 5.

\section{Syntactic variation-research overview}

Taking Kayne's (1996) theory of microvariation as a starting point, a broad spectrum of studies and projects on dialect syntax have 
emerged in Europe over the past 30 years, primarily with theoretical interests and goals. Besides numerous individual studies (cf., e.g., Poletto, 2000), there are also several dialect syntax (atlas) projects taking place across Europe. Most of these projects are thematically and methodologically connected within the network European Dialect Syntax (Edisyn) (<www.dialectsyntax.org >). Their thematic integration primarily manifests in a shared emphasis on doubling phenomena in all European syntax projects. Their methodological integration is based, in part, on overlapping and standardized methods of data collection, facilitating the comparison of data across the individual studies. In this respect, the Syntactische Atlas van de Nederlandse Dialecten (SAND) ('Syntactic Atlas of Dutch Dialects') has set standards that have become well established (cf. Barbiers, 2005; Barbiers, van der Auwera, Bennis, Boef, de Vogelaer \& van der Ham, 2008).

Regarding the current state of research on German variation, research on the areal-social dimensions of syntactic variation previously focused almost exclusively on the syntax of dialects. Research of dialect syntax in the German-speaking area emerged at the end of the 19th century, when important studies, such as Schiepek $(1899,1908)$ appeared. However, it is only since the 1980s that research on German dialect syntax came back into focus, first concerning methodological considerations of its practicability (Patocka, 1989; Tatzreiter, 1989) and later mainly as the object of theoretical linguistic research (cf., e.g., Abraham \& Bayer, 1993; Bayer, 1984; Grewendorf \& Weiß, 2014; Haider, 1993; Weiß, 1998). In addition to syntactic theory, German dialectology has started to address questions regarding syntactic structure. Around the beginning of the new millennium, a veritable "boom" in research on dialect syntax can be observed (cf., e.g., Fleischer, 2002; Schallert, 2014; Seiler, 2003; among many others).

Besides phenomenon-oriented studies, large-scale investigations of dialect syntax in the form of atlases have also emerged. Here, the Syntaktischer Atlas der Deutschen Schweiz (SADS) ('Syntactic Atlas of Swiss German Dialects') serves as a model for atlases of German dialect syntax. ${ }^{4}$ Additionally, syntactic data collected in the context of the Bayerische Sprachatlanten ('Bavarian Language Atlases') should be mentioned (cf., e.g., Eroms \& Spannbauer-Pollmann, 2006 for Low Bavarian). Over the past two decades, additional projects on dialect syntax in the German-speaking area have been developed: the project Syntax Hessischer Dialekte (SyHD) ('Syntax of Hessian Dialects'), ${ }^{5}$ and the project Syntax des Alemannischen (SynAlm) ('Syntax of Alemannic'). ${ }^{6}$ Furthermore, the Siegerländer Sprachatlas (SiSal) ('Language Atlas of the Siegerland') conducted widespread dialect syntactic surveys by using the SyHD questions. ${ }^{7}$ Regarding 'higher' varietal sections in the vertical dialect-standard spectrum of variation, two important and innovative projects should be mentioned: Firstly, the Atlas zur deutschen Alltagssprache (AdA) ('Atlas of Colloquial German'), ${ }^{8}$ which also surveys at least some syntactic phenomena of 'intermediate varieties' (regiolects; cf. Lenz 2010) of the dialect-standard-axis. Secondly, the project Variantengrammatik des Deutschen ('Regional Variation in the Grammar of Standard German'), ${ }^{9}$ which focuses on national and regional differences in the grammar of the (written) German standard language in German speaking countries and areas. While these two projects concentrate on "intermediate" respectively "higher/ highest" varieties, they neglect the "lower/lowest pole" of vertical variation, i.e., the dialects.

To date, the detailed research methods of large-scale areallinguistic projects in Europe, with a focus on nonstandard syntax, have contained many similarities. The methodical standards often include questionnaire-based surveys, deployed either in written form (by post or online $\mathrm{e}^{10}$ ) and without the presence of a field worker or in the context of oral interviews. In these written or oral questionnaires, different types of questions or tasks are employed. Of these, translation and assessment tasks (acceptability tests) have the longest tradition and are most commonly used. ${ }^{11}$ Other types of tasks used include puzzle tasks, image description, sequences of images description and completion tasks, as well as combinations of these tasks (cf., e.g., Lenz, 2016 for SyHD). The SyHD project is the first project to employ LPEs in the context of local face-to-face surveys, in addition to written questionnaires (cf. Fleischer, Kasper \& Lenz, 2012; Fleischer, Lenz \& Weiß, 2015; Lenz, 2016, 2017). In the SFB DiÖ study, more traditional survey methods for collecting data on syntactic variation are supplemented by computer supported LPEs (with experiment software) and with a pseudo-randomized order of the tasks.

\section{Language Production Experiments (LPEs) — in general and in particular for the SFB DiÖ}

As previously mentioned, large-scale projects have used LPEs in a broad sense in the past (e.g., SyHD). However, there is little literature on the details of this method, e.g., the experimental software used in the projects, the underlying conceptions on which the tasks are based and the exact kind of presentation (described for example in Breuer, 2017a; Kallenborn, 2016; Lenz, 2009). This article discusses the fundamental aspects of the experiments: While LPEs can differ in both appearances and in the details of the setting, their standardization is a shared characteristic. As described explicitly in, for example, Cornips \& Poletto (2005: 949) and Kallenborn (2016: 64-65), the use of written questionnaires constitutes a standardized procedure, but it does not provide oral language production data and has less controllable contextual or situational parameters. Traditional oral questionnaires, however, are strongly manipulated by the field worker, have less standardized sequences, and work with a minimum of media (images, if at all). Therefore, we define "Language Production Experiments" in the context of the SFB DiÖ, as a quasi-experimental test setting in which standardized multimodal stimuli are presented in standardized sequences to evoke spoken language data and to test the influence factors on specific linguistic phenomena (cf. Breuer \& Bülow, 2019: 256). ${ }^{12}$ However, this definition contains some restrictions: Because it is a standardized method, it should be replicable and some (linguistic) influence factors should be effectively controlled in the test design. There is an advantage which comes from the restrictions of this method: Because several factors are controlled, researchers can use LPEs to elicit linguistic data that is comparable between different projects. Kallenborn (2016: 69) emphasizes the high inter- and intra-individual comparability. Therefore, an LPE can be used to compare data between different speakers, or different linguistic reactions of the same person to the same linguistic influence factor or similar stimuli. Thus, LPEs are a suitable method for variationist linguistic surveys, especially for projects that focus on more than one linguistic variety (e.g., standard versus dialect). As previously mentioned, an LPE can be comprised of any number of different experimental settings in terms of the media used (images, sounds or videos) and are characterized by the presentation method (digital or computer supported) and the low influence of the investigator, and therefore the level of standardization of the LPEs.

The following sections focus on the LPEs used in the SFB DiÖ: These LPEs are employed within the framework of a multidimensional research project, which attempts to survey and analyze the complex spectrum of variation and varieties of German in Austria (cf. map 1-4 below), the predominant part of which falls into the 
Bavarian dialect area which belongs to the "East Upper German" dialect area. Beyond Austria, the Bavarian dialect area also extends far into South-Eastern Germany and into Northern Italy (South Tyrol) (cf. Wiesinger, 1983). The far West of Austria-Vorarlberg and parts of Tyrol-is part of the Alemannic ("West Upper German") dialect area.

The LPEs are an integral part of the complex methodology of data elicitation used by one of the nine project parts of the SFB $\mathrm{DiÖ}$, project part 03, which investigates language repertoires and variation spectra in rural regions in Austria (https://dioe.at/ en/projects/task-cluster-b-variation/pp03/). In contrast to previous variationist linguistic research on German, which focused primarily on (segmental) phonetics/phonology, project part 03 additionally considers morphological and syntactic variation. Besides more open and natural conversational settings (namely interviews and "conversations among friends") in which the speakers are recorded, standardized elicitation methods (like LPEs) are also used (cf. Lenz, 2018b). Putting the methodological approaches in a comprehensive context, a classification of the "task sets" (cf. below, Table 1) used in the LPE of the SFB DiÖ is suggested. This experimental setting consists of two runs (e.g., Breuer, 2017a; Kallenborn, 2016): one aiming to evoke variants in the (intended) standard (LPE-S) and another aiming to evoke variants in the (intended) dialect (LPE-D). Between these runs there is a short break and another test setting that uses translation tasks to target phonological and grammatical (mainly morphological) phenomena, some which overlap with the phenomena elicited through the LPEs (for a comparison of speaker behavior across settings, cf. Fingerhuth \& Breuer, accepted). However, because they are designed to complement each other, these two runs can be considered as one single LPE: For each task targeting a syntactic variable in the standard, there is a corresponding task targeting the same variable in the dialect. These complementary tasks differ in the varieties represented within the audio stimuli. For example, the tasks targeting standard use recordings of an Austrian newscaster differ from those targeting dialect recordings of a competent speaker from the investigated locations' local dialect. Furthermore, the complementary tasks can differ depending on the image or video presented, ${ }^{13}$ but only in ways that are unlikely to influence the syntactic variable under consideration, thereby reducing the repetition effect (e.g., Breuer, 2017a: 99; Breuer \& Bülow, 2019: 261). The tasks of both runs (LPE-S and LPE-D) occur in a pseudo-random order.

Within this project, the LPE is embedded in a whole survey setting, which can be described as a face-to-face survey. A field worker is present throughout the entire LPE to control the progress of the tasks. If necessary, the field worker can repeat a task (using the computer, see below) or ask further questions, thereby influencing the answer and behavior of the speaker. It is important to note that any additional inquiries or "influence" from the interviewer are marked as such during data processing. This allows researchers to distinguish spontaneous answers from "influenced" second or third answers in their analyses. Vice versa, the speakers can consult the field worker if they encounter any problems responding to a task. The LPE in the SFB DiÖ is "computer supported" (Breuer \& Bülow, 2019: 257) and uses OpenSesame as experimental software. ${ }^{14}$ An important feature of the software is the possibility for pseudo-randomization of the tasks in each run of the LPE (e.g., Breuer, 2017a: 97). This randomization helps to avoid the effects of task serialization across the data of different speakers. It is pseudorandomized to prevent tasks from targeting a particular syntactic variable and from being followed by another task which is aimed at that same variable. OpenSesame documents the chronological order of a given LPE run in a file, which can easily be imported into the analysis tool. This way, the speaker's response to a specific task can be located in the audio recording. However, using OpenSesame requires that all LPE tasks are presented using a notebook computer. All tasks of the SFB DiÖ LPEs use audio stimuli and most also use visual stimuli, such as images or videos. In general, the tasks avoid written text in the visual stimuli. Avoiding written text is intended to enhance the "oral character" of the tasks, as the LPEs aim at eliciting oral language production. In total, each LPE run consists of 109 tasks that target 13 distinct syntactic phenomena. The tasks are organized into sets that target a particular syntactic phenomenon according to their structure. Each task within a set has the same formulation, the same kind of media used as stimuli, and the same sequence of stimuli to target the same syntactic phenomenon. One task aims to evoke different syntactic variants or to evaluate different syntactic control factors simultaneously. The entire SFB DiÖ LPE consists of 218 tasks grouped in 50 task sets. The general characteristics of the LPEs (cf. Table 1) applies to all tasks. However, the tasks differ in their details. This includes the media used, the type (completion or question), whether a (narrative) context is given, the level of 'suggestion', (e.g., by specifying given words in the stimulus) and if a task is more open or closed. ${ }^{15}$

Table 1 shows a classification of the task sets that target eight exemplary syntactic phenomena in the SFB DiÖ LPEs. The table provides an overview of the tasks and their essential methodical characteristics. The order of appearance mirrors different syntactic fields. Firstly, phenomena of complex noun or determiner phrases (NPs, or DPs, depending on the theoretical perspective), specifically the use of indefinite articles with mass nouns, determiner doubling, and the use of alternative constructions for the expression of adnominal possession. The second group contains phenomena of subordinate clause introduction: variation in the C-Domain in the form of doubly-filled COMP and inflected complementizers, and variation in the introduction of relative clauses. The last group concerns verbal syntax and addresses progressive constructions, final infinitival constructions, and German GET passives. To provide deeper insights into the various types of task sets differentiated in Table 1, we illustrate at least one concrete LPE for each syntactic field. A short description of the syntactic phenomenon is followed by a summary of the state of research with a focus on variationist linguistics aspects relevant for the SFB DiÖ and therefore for the analyses of the data. The third section portrays the design of the tasks created for the phenomena. In every instance, concrete language examples will be taken from the SFB DiÖ LPE. These SFB DiÖ language examples will come from either the experiment tasks targeting dialect (LPE-D) or those targeting standard (LPE-S). In addition to the intended variety, the Austrian location of the survey, as well as the generational category of the speakers ("old" versus "young"), will be given.

\section{Example I: LPE on "determiner doubling"}

LPE-type: Closed completion tasks with image and video stimuli, with written text, without narrative context and with a high level of suggestion. Short description: Determiner doubling refers to the phenomenon of a noun phrase (NP) with an adjectival attribute that is preceded by an intensifying element (particle) and occurs with "two articles." (1.1) provides an example of the phenomenon. This is different from the patterns in (1.2) and (1.3), which feature only one article, placed either in a preceding or intermediate 
position (cf. Kallulli \& Rothmayer, 2008; Lenz, Ahlers \& Werner, 2015; Strobel \& Weiß, 2017).

(1) Examples for Determiner Doubling (and alternative constructions) from the SFB DiÖ

(1.1) Determiner doubling

a gonz
young)
$\begin{aligned} & \text { a. ART completely } \\ & \text { 'a very lovely dog' }\end{aligned}$

(1.2) Single determiner in preceding position

$\begin{array}{lll}a \quad \text { gonz } & \text { liaber } & \text { Hund (LPE-D, Neumarkt/ } \\ \text { Ybbs-old) } & & \\ \text { a. ART completely } & \text { lovely } & \operatorname{dog} \\ \text { 'a very lovely dog' } & & \end{array}$

(1.3) Single determiner in intermediate position

$\begin{array}{llll}\text { ganz } & \text { en } & \text { liaber } & \text { Hund (LPE-D, Raggal-young) } \\ \text { completely } & \text { a. ART } & \text { lovely } & \text { dog } \\ \text { 'a very lovely dog' } & & \end{array}$

State of Research: Determiner doubling has seen considerable research over the past decades. Occurrence of the phenomenon is documented primarily in Bavarian and Alemannic (both Upper German areas) and less frequently in Rhine Franconian (a West Central German area) and the Westphalian (a West Northern German area) dialects of German (cf. Henn-Memmesheimer, 1986). Research suggests that the occurrence of determiner doubling is dependent on the accompanying intensifying particle. Regarding Bavarian, Merkle (1975: 89) describes doubling of indefinite determiners as being possible with so ('such'), ganz ('completely'), recht ('quite'), viel ('much'), bisschen ('some'), and wenig ('little'), as well as sehr ('very') in urban varieties, although Merkle states that sehr ('very') is not traditionally part of Bavarian varieties. East Upper German data elicited with written questionnaires requesting the acceptability of determiner doubling with ganz ('completely') indicate that it is a common phenomenon throughout the entire Bavarian dialect area that may be gaining use as intergenerational comparison suggests (cf. Lenz et al., 2015). Determiner doubling has been further explored in Swiss German (a West Upper German area): Steiner (2005) focused primarily on regional and sociodemographic factors regarding doubling in the context of ganz ('completely'). Her results indicate various degrees of acceptability across German-speaking Switzerland, with high acceptability appearing in northern Switzerland. Steiner's findings also indicate a particularly high degree of acceptability among younger speakers in comparison to older Swiss German speakers.

As described in regard to Bavarian, there also appear to be marked differences in acceptability of determiner doubling when in combination with different particles in Switzerland (cf. Richner-Steiner, 2011). Notably, Kallulli \& Rothmayr (2008: 105) state that definite determiner doubling in Swiss German is not limited to ganz ('completely'), as described for Bavarian, but also appears with viel ('much'), although the acceptability appears to be rather low. In addition to these empirical studies on the phenomenon in the German language area, there are various approaches to the theoretical interpretation of determiner doubling. Kallulli \& Rothmayr (2008) classify the phenomenon as the parallel presence of a quantifier and a determiner rather than the actual doubling of a determiner. Alternative work has suggested there may be a semantic distinction between the different variants of determiner placement and doubling exemplified in (1), including the possibility that duplication indicates emphasis. However, the sparse empirical evidence on the different theoretical interpretations has so far remained inconclusive.

In the SFB DiÖ LPE: Based on existing research, the experiments aim to test the production of determiner doubling (and its constructional variants) in three sets consisting of two prompts each. The sets aim to elicit the intensifiers ganz ('completely'), sehr ('very'), and so ('such') in combination with attributive adjectives. In each set, one prompt targets the adjective böse ('bad'), the other lieb ('lovely'). The prompts for the LPE combine an audio recording with an image of a dog and two moving words (Fig. 1). In each prompt, a drawing of a dog that suggests either a bad or an adorable animal appears on the centre of the screen. The drawings were

Table 1. Task sets (types) used during the SFB DiÖ LPE for the elicitation of syntactic phenomena

\begin{tabular}{|c|c|c|c|c|c|c|c|}
\hline \multirow[b]{2}{*}{ syntactic phenomenon } & \multicolumn{3}{|c|}{ stimulus } & \multirow{2}{*}{$\begin{array}{l}\text { given } \\
\text { context }\end{array}$} & \multirow{2}{*}{$\begin{array}{c}\text { completion } \\
\text { task }\end{array}$} & \multirow{2}{*}{$\begin{array}{l}\text { open } \\
\text { task }\end{array}$} & \multirow{2}{*}{$\begin{array}{c}\text { degree of } \\
\text { suggestion }\end{array}$} \\
\hline & written & image & video & & & & \\
\hline \multicolumn{8}{|c|}{ nominal syntax } \\
\hline \multirow[t]{2}{*}{ indef. article before mass nouns } & - & + & - & - & + & - & 2 \\
\hline & $-1+$ & + & - & - & + & $+1-$ & 2 \\
\hline determiner doubling & + & + & + & - & + & - & 2 \\
\hline adnominal possession & - & + & - & + & + & - & 3 \\
\hline \multicolumn{8}{|c|}{ clause linkage phenomena } \\
\hline variation in the $\mathrm{C}$-domain & + & + & - & + & + & - & 3 \\
\hline \multirow[t]{2}{*}{ introduction of relative clauses } & - & - & + & + & + & - & 3 \\
\hline & - & + & - & + & + & - & 3 \\
\hline \multicolumn{8}{|c|}{ verbal syntax phenomena } \\
\hline \multirow[t]{2}{*}{ progressive constructions } & - & - & + & - & - & + & 1 \\
\hline & - & - & + & + & + & - & 3 \\
\hline final infinitival constructions & - & + & + & - & + & - & 2 \\
\hline GET passives & - & - & + & - & - & + & 1 \\
\hline
\end{tabular}




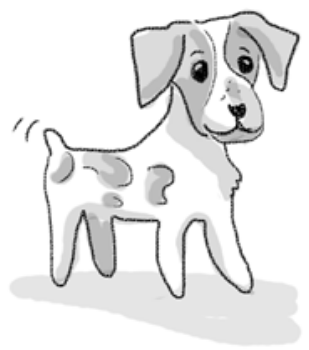

LIEB

\section{SO}

Figure 1. Example of the visual stimulus depicting the phenomenon group of the "determiner doubling." It is accompanied by an auditive stimulus Oh, das ist aber . ('Oh, this is really ... '). The intensifying particle plus adjective (in this example: so 'such' and lieb 'lovely') appear in a circular motion.

selected with the goal of potentially triggering an emphatic response. Beneath the drawing, a combination of an intensifying particle and adjective corresponding to the dog's character appears. To reduce the suggestion of a particular word order, the two words appear in a video clip with a constant circular rotation. Additionally, a recording is played that begins a sentence with Oh, das ist aber ... ('Oh, this is really ...'), prompting the participant to complete the sentence using the displayed combination of adjective and intensifying particle, as well as an indefinite determiner.

\section{Example II: LPE on "variation in the C-domain"}

LPE Type: Closed completion tasks with image stimuli, with written text, with narrative context and a high level of suggestion. Short Description: Subordinate clauses in Upper German dialects (especially in Bavarian) may be introduced by patterns that are different from standard German. One of these patterns is commonly referred to as either "inflected complementizer" or "complementizer agreement" (subsequently referred to as CA; cf. Weiß, 2005), another as "doubly-filled COMP" (subsequently referred to as DFC; cf. Bayer \& Brandner, 2008; Fingerhuth \& Lenz, accepted; Weiß, 2017). The LPEs in the SFB DiÖ target both phenomena, which have been rarely investigated in connection with each other (for exceptions, cf. Fingerhuth \& Breuer, accepted; Fingerhuth \& Lenz, accepted; Weiß \& Strobel, 2018). They are illustrated in (2) by means of SFB DiÖ examples from the Austrian Bavarian dialect areas. Regarding Bavarian, elements that are in the complementizer position (COMP) may show agreement with the sentence subject, particularly in the second person (2PL or 2SG). The examples in (2.1) and (2.2) illustrate this. $\mathrm{Ob}$ ('if) and bis wann ('until when') appear in immediate proximity of the suffixes $-s$ (2PL) and $-s t$ (2SG). While traditional grammar does not consider subjunctions such as $o b$ ('if) and wh-words (such as wann 'when') to be inflecting, the occurrence of these morphemes in dependence of the verbal inflexion of the sentence suggests otherwise and therefore inspires the term "complementizer agreement." (2.3) illustrates a case of DFC: The subordinate clause is first introduced by the complex wh-phrase wia viel Leit (standard German: wie viele Leute how many people'), and additionally by the subordinating conjunction dass 'that' which appears as a second element in the C-domain motivating the label "doubly-filled COMP." CA is also possible in cases of DFC, as illustrated in (2.4).
(2) Examples for variation in the C-domain from the SFB DiÖ

(2.1) Complementizer agreement (CA 2PL)
ob=s eß morgen orbeiten werdts
(LPE-D, Neckenmarkt-young)
if=CA.2PL you tomorrow, work.INF will.2PL
'if you will work tomorrow'

(2.2) Complementizer agreement (CA 2SG)

bis wann=st morgen die Hausübung fertig host
(LPE-D, Neckenmarkt-young)
until when=CA.2sG tomorrow the homework done have.2sG
'until when you will have done your homework tomorrow'

(2.3) Doubly-filled COMP (without CA)

wia viel Leit dass du nächste Wochen in der Kirchen sehng wirst

(LPE-D, Steyrling-young)

how many people that you next week in the church

see.INF will.2sG

'how many people you will see in church next week'

(2.4) Doubly-filled COMP (with CA 2PL)

wia viel Schulde dass=ets habets (LPE-D, Tarrenz-young) how much debt that $=$ CA.2PL have. $2 \mathrm{PL}$

'how deep you are in debt'

State of Research: Both phenomena have been extensively discussed over the past decades. While research has focused less on areal distribution and more on the implications of the phenomenon for theories of grammar, there is considerable documentation of its regional spread. Weiß (2005) describes CA as a phenomenon that appears in most Continental West Germanic dialects, although he emphasizes that there is considerable variation between different dialects. While some dialects have a minimal system, where only the 2SG shows CA, other dialects show agreement for all persons. Regarding Austria, the phenomenon appears predominantly in the Central Bavarian dialect area and here in the 2SG and 2PL (cf. Fingerhuth \& Lenz, accepted). In the 2PL, Central Bavarian varieties predominantly show the morpheme $-s$, but the morpheme - $t$, common in Northern Bavarian, has also been documented (cf. Lenz et al., 2015: 13-15). In varieties that demonstrate the morpheme - $t$, it is phonologically mostly identical to the corresponding verb ending. This is more generally the case with the 2SG, where the CA-morpheme -st is phonologically identical to the 2SG verbal inflection (cf. (2.2)). The exact nature of the CA is debatable (cf. Bayer, 1984; Fuß, 2008; Gruber, 2008). Weiß $(2005,2017)$ interprets the historic origin of CA in the reanalysis of subject clitics as inflectional morphemes. Regarding DFC, a wider distribution can be assumed, extending from mainland and insular Scandinavian (cf. Larsson, 2014) over West Flemish to Alemannic and Bavarian dialects (Penner, 1993; Schallert, Dröge \& Pheiff, accepted). Different factors influencing the occurrence of DFC have been discussed, including a frequent co-occurrence with stressed interrogative pronouns, as well as the occurrence in dependence on the complexity of $w h$-words, and animacy (Bayer \& Brandner, 2008; Fingerhuth \& Lenz, accepted; Schallert et al., accepted).

In the SFB DiÖ LPE: Existing research suggests that the appearance of CA and DFC is connected to at least two linguistic factors: the grammatical features of the verbal inflection and the type and complexity of the element(s) in the C-domain. Our LPE therefore attempts to elicit subordinate clauses in four sets of three tasks each. Each set aims to elicit a different subordinating element: wann ('when') as a simplex wh-adverb; wie viele Leute ('how many people') as a complex NP with an interrogative 


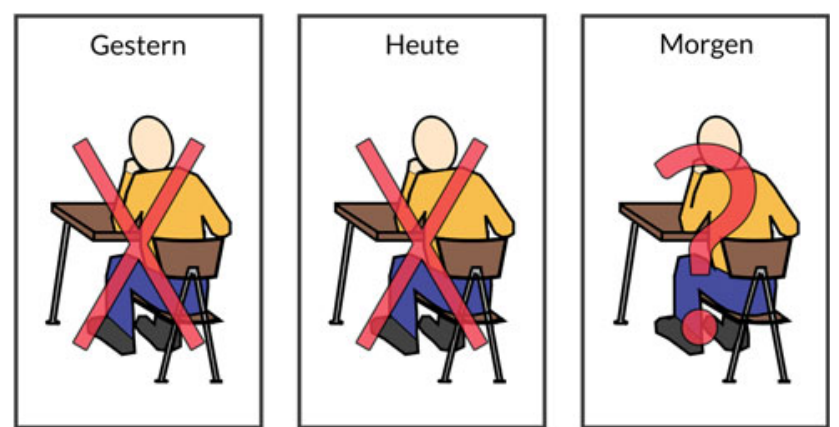

Figure 2. Example of the visual stimulus depicting the phenomenon group of the "variation in the complementizer domain." It is accompanied by an auditive stimulus (e.g. 'You didn't do your homework yesterday (gestern). You haven't done it today (heute).') that ends with the statement Ich frage mich, ... ('I wonder, ... ') for completion by the participant.

$w h$-determiner; $o b$ 'if' as a simplex subordinating conjunction; and bis wann 'until when' with a wh-element within a PP. Within these four sets, three prompts attempt to elicit sentences with specific verbal inflection (2SG, 2PL, and 1PL). The experiment uses audio-visual prompts with an embedded written context (single words) that correspond to a series of events narrated by a recorded voice (cf. Fig. 2). The first two events provide a context of past and present events (e.g., Letztes Jahr habt ihr 3 Leuten auf dem Hof geholfen. Dieses Jahr habt ihr 5 Leuten auf dem Hof geholfen. 'Last year you helped 3 people on the farm. This year you helped 5 people on the farm.'). The third event is placed in the future by the text in the visual stimulus (e.g., nächstes Jahr 'next year') and marked with a question mark. The narrator stops after uttering Ich frage mich, ... ('I wonder, ...'), leaving the completion of the sentence to the participant, e.g., with wie vielen Leuten ihr nächstes Jahr auf dem Hof helft ('how many people you will help on the farm next year'). The prompts aim to elicit sentences as follows: 1.) with the subordinating element wann ('when'): Fabian/Martin treffen ('meet Fabian/Martin', 2SG), Bernhard/Karl besuchen ('visit Bernhard/Karl', 1PL), Paul/Michael helfen ('help Paul/Michael', $2 \mathrm{PL}$ ); 2.) with the introducing phrase wie viele + NP ('how many + NP'): Leute sehen ('see people', 2SG), Freunde treffen ('meet friends', 1PL), Leuten helfen ('help people', 2PL); 3.) with the subordinating element $o b$ ('if'): zur Schule gehen ('go to school', $2 \mathrm{SG}$ ), in die Stadt fahren ('go to town', 1PL), arbeiten ('work', $2 \mathrm{PL})$; 4.) with the introducing PP bis wann ('until when'): Hausaufgaben fertig haben ('have finished homework', 2SG), arbeiten ('work', 1PL), schlafen ('sleep', 2PL).

\section{Example III: LPE on "final infinitival constructions"}

LPE Type: Closed completion tasks with image and video stimuli, without written text, with no narrative context and a medium level of suggestion. Short description: In German, there are different infinitival constructions to express intention, purpose, and goal: While the construction consisting of $u m z u$ ('in order to') + infinitive (cf. (3.1)) is accorded the status of standard language (cf. Zifonun, Hoffmann \& Strecker, 1997: 829), the variants with für $z u(m)$ ('for to') or $z u m$ ('to=the.DAT') + infinitive (cf. (3.2)/ (3.3)/(3.4)) are considered non-standard (cf. Demske, 2011: 38). Final clauses introduced by dass ('that') (cf. (3.6)) or damit ('so that') (cf. (3.5)) are alternatives to final infinitival constructions.
(3) Examples for final infinitival constructions from the SFB DiÖ

(3.1) Construction with $u m z u$ 'in order to'

$$
\begin{aligned}
& \text { um zu schlafen (LPE-S, Steyrling-young) } \\
& \text { in order to sleep.INF } \\
& \text { 'in order to sleep' }
\end{aligned}
$$

(3.2) zum construction with incorporation of a generic object

$$
\begin{aligned}
& z u-m \quad \text { Rosen mahen (LPE-D, Allentsteig-young) } \\
& \text { to-the.DAT lawn mow.INF } \\
& \text { 'for the mowing of the lawn/in order to mow the lawn' }
\end{aligned}
$$

(3.3) zum construction with prepositional attribute of the nominalized infinitive

zu-m an-nahen von an Knopf auf a Hosen (LPE-D, Weißbriach-young)

to-the.DAT on-sew.INF of a button onto a trouser 'for the sewing of a button [. . .]/in order to sew a button onto a pair of trousers'

(3.4) zum construction with a complex incorporated direct object

zu-m an Nagel in-s Holz ihi-schlogen (LPE-D,
Raggal-young) to-the.DAT a nail in-the wood in-hammer.INF 'for the hammering of a nail $[\ldots] /$ in order to hammer a nail into the piece of wood"

(3.5) Final clause introduced by damit 'so that'

damit ma wandern kann geh (LPE-D, Neckenmarkt-old) so that one hike.INF can go.INF 'so that one can go hiking'

(3.6) Final clause introduced by dass 'that'

dass man den Nagel in das Holz schlagen kann (LPE-S, Oberwölz-old)

that one the nail into the wood hammer.INF can 'so that one can hammer a nail into the piece of wood'

State of Research: Until now, few publications have addressed infinitival constructions in German. Regarding the areal distribution of the variants, Donhauser (1989) and Weiß (1998) observe the occurrence of the infinitival construction with $z u m$ 'to-the.DAT' in Bavarian, Kallenborn (2016) in Western Central German varieties, and Seiler (2005) in German-speaking Switzerland. The question whether the construction with $z u m$ 'to-the.DAT' in Bavarian Dialects is verbal or nominal is a large issue in literature on infinitival constructions ${ }^{17}$. In Alemannic dialects, the infinitival construction with $z u m$ is interpreted as verbal, since any number of complements can be put between $z u m$ and the infinitive, and even a complex direct object is permissible in the construction (cf. Schallert, 2013; Seiler, 2005). Such constructions (cf. (3.4) for Alemannic Raggal) are uncommon in Bavarian, where the strategy to deal with complements is to incorporate generic objects only (cf. (3.2)) or the complements are added in the form of a prepositional attribute (cf. (3.3)). While Bayer (1993) and Zehetner (1985) interpret the Bavarian infinitive as nominal, Weiß (1998) concludes that there are two types of constructions with zum 'to-the.DAT' in Bavarian, phrases with a nominal infinitive and phrases with a verbal infinitive (cf. Weiß, 1998: 242ff.). As the the map for "um/für zu kaufen" ('in order to' / 'for to buy') of the 'Atlas of Colloquial German' (AdA) reveals, the für $z u(m)$ 'for to' construction seems to be predominant in 'intermediate' colloquial varieties of Western Central and Western Upper German. In addition, few occurrences can be found in the Bavarian area in the Southeast of Germany and in Austria (cf. <www.atlas-alltagssprache.de/runde-3/f04e/>). 


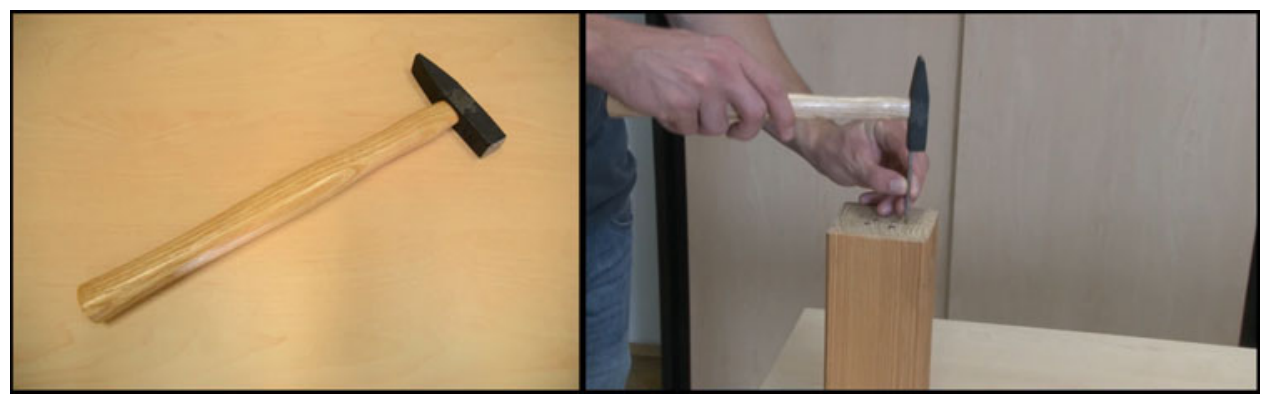

Figure 3. Example of the visual stimulus depicting the phenomenon group of the "Final infinitival constructions." This is parallel to the auditive stimulus Das braucht man, ... ('This is required, ...').

In the SFB DiÖ LPE: Within the framework of the SFB DiÖ experiments, a total of 14 tasks ( 7 in the dialect and 7 in the standard run of the LPE) are used to study the usage frequencies and syntactic-semantic selection parameters of the final infinitival constructions. As concrete linguistic control factors, the valency of verbs is tested by presenting actions intending to evoke: intransitive verbs (wandern 'to hike' and schlafen 'to sleep'), transitive verbs ((den Rasen) mähen 'to mow (the lawn)' and (Geldscheine in Stücke) schneiden 'to cut (banknotes into pieces)'), and ditransitive verbs ((einen Nagel in ein Stück Holz) schlagen 'to hammer (a nail into a piece of wood)' and (einen Knopf an eine Hose) nähen 'to sew (a button onto trousers)').

The design of Kallenborn's (2016) speech production experiment is used in extended form in the SFB DiÖ; it exposes the speakers to a complex stimulus consisting of a video clip, a picture and an audio recording (cf. Fig. 3). To ensure that the function of the intended object (e.g., hiking boots or a lawnmower) is in the focus of the speaker's description, a picture of these objects is explicitly shown beside the video. The purpose of the video clip is to portray the specific action for which the object is required. The speakers must complete the sentence Das braucht man, ... ('This is required, ...').

\section{Case study: LPE on German GET passives}

The following section provides a detailed case study of one selected linguistic phenomenon to illustrate the productivity and validity of LPEs for the analysis of syntactic variation. At the same time, this section reflects on potential problems inherent to the method. For several reasons, described in more detail below, the analysis focuses on the German GET passive. Section 4.1 describes the phenomenon in general and reviews previous research. Section 4.2 provides a (predominantly methodological) discussion of the data gathered by the SFB DiÖ by LPEs.

\subsection{General remarks on the German GET passives}

The phenomenon chosen to illustrate methodology and application of the LPEs has been referenced with different terms in previous research: ${ }^{18}$

1. GET passive (or, in German literature, "kriegen/bekommen/ erhalten passive"). This term refers to the pattern used in German. This non-canonical type of passive uses an auxiliary verb from the semantic network of transfer verbs (cf. Lenz, 2013b) (usually kriegen 'to get' or bekommen 'to get/receive', less frequently erhalten 'to obtain') that combines with a past participle (cf. (4.1) and (4.2)). Selection of the auxiliary depends on numerous factors-semantic, syntactic, stylistic, and sociolinguistic - in complex interaction (cf. Lenz, 2013a). Except for a few areas, kriegen serves as the auxiliary in dialect varieties of German. Only in some (predominantly Western) Upper German dialects (e.g., Swiss German varieties), bekommen is the equivalent auxiliary. However, even where the dialectal GET passive appears with bekommen, it is restricted to specific syntactic-semantic contexts that indicate a presently low degree of grammaticalization of the bekommen passive. When considering areal varieties with greater coverage than the base dialects (i.e., regiolects, cf. Lenz, 2010), kriegen and bekommen co-occur more frequently as auxiliaries. bekommen generally appears more frequently in contexts closer to standard language than kriegen, which bears stronger associations of non-standard varieties. The auxiliary erhalten, however, appears neither in dialects nor regiolects but only in the context of standard language, particularly in writing with a rather high degree of formality. ${ }^{19}$ In these contexts, erhalten functions as an auxiliary that is stylistically marked as a "higher" variant, while bekommen appears as a rather unmarked, neutral auxiliary (cf. Eroms, 2000: 396; Lenz, 2013a).

2. Dative passive: While the subject of the German werden passive (Vorgangspassiv 'event passive') is equivalent to the direct object (accusative) of the corresponding active sentence (cf. (4.3) versus (4.4)), the subject of a dative passive is (usually) equal to the indirect dative 'object' (either required by the predicate's valence structure or as a free attribute) of the corresponding active sentence (cf. (4.1)/(4.2) versus (4.4)). For the Bavarian dialect area, the term dative passive is to some extent misleading, because many non-standard varieties exhibit syncretism of dative and accusative in a single oblique case.

3. Recipient passive, addressee passive, beneficiary passive: These alternative terms for the construction capture the prototypical semantic roles of the subjects that occur most frequently (and historically first; cf. Lenz, 2012) in German GET-passive constructions.

(4) Examples for GET-passive and alternative constructions from the SFB DiÖ

(4.1) GET passive (with kriegen 'to get' auxiliary) Der MoO kriagt d=Hoa gschnitten. Allentsteig-young)

[the man].Nom. gets the=hair.ACC cut.PASTPART 'He is getting his hair cut.'

(4.2) GET passive (with bekommen 'to get/receive' auxiliary) Der Mann bekommt seine Haare geschnitten. (LPE-S, Allentsteig-young) [the man].NOM gets [his hair].ACC cut.PASTPART 'He is getting his hair cut.'

(LPE-D,

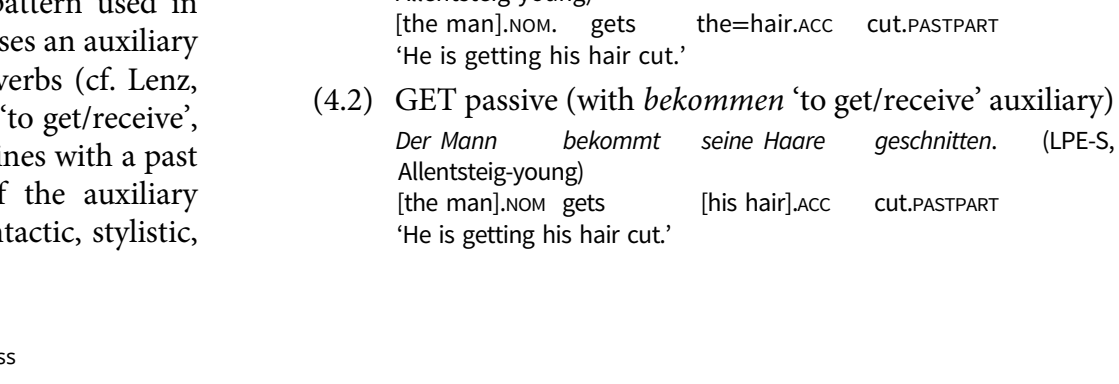


(4.3) Event passive (with werden 'to become' auxiliary)

Dem Maa werden $d=$ Hoar
Raggal-young)
[the man].DAT becomes [the=hair].NOM cutt.PASTPART
'The hair is being cut (for him).'

(4.4) Active construction with "recipient" (beneficiary) as dative complement

Jemand schniedet ihm d=Hoar. (LPE-D, Raggal-young) someone.NOM cuts he.DAT [the=hair].ACC

'Someone is cutting his hair.'

Over the past two decades, few other syntactic constructions have drawn more attention from both areal variationist linguistics and non-variationist theoretical linguistics. This interest highlights the phenomenon's value for different linguistic approaches and allows the researcher to access a wide range of findings from previous analyses. Based on this previous research on the dative passive from areal-linguistic work, the construction's grammaticalization has progressed with considerable regional differences within the Germanic language area. Grammaticalization appears to have progressed the farthest in Luxembourg and the West Central and West Low German areas (Lenz, 2007, 2008, 2009, 2018a). This regional pattern can (to a varying degree) be found in all layers of vertical variation in the German language area, ranging from dialects to the written standard language (Lenz, 2013a). Regarding Upper German areas (which includes Austria), a degree of grammaticalization for the GET passive appears only with ditransitive verbs in combination with subject referents that have the semantic role of beneficiary or recipient. Mono- and intransitive lexical verbs that appear with dative passives in (especially the Western parts of) Central and Low German areas (e.g., Er kriegt/bekommt/*erhält geholfen. 'He is getting helped.'), or constructions where the subject referent appears in the semantic role of "maleficiary" or "loser" of a transfer (e.g., Er kriegt/bekommt/*erhält etwas gestohlen. 'He is getting something stolen./Something is stolen from him.') appear not to be possible in Upper German varieties at this point in time (Lenz, 2009, 2013b, 2018a). The following aspects make the GET passive a particularly suitable phenomenon to reflect upon the potential as well as the limitations of LPEs as a method of data collection:

Substantial previous research: The GET passive has inspired considerable research from different linguistic subdisciplines. This alone speaks to the phenomenon's relevance to a broad linguistic audience. The different theoretical and methodological approaches taken in previous work provide a rich pool for the investigation of research methodology. From this perspective, the phenomenon itself functions as a means to an end.

Complex areal and social distribution: Areal-linguistic research indicates that grammaticalization of the GET passive (presently) has progressed to differing degrees in the German-speaking area. The Upper German area (which includes Austria) is an area in which the construction is in a comparatively early stage of grammaticalization. The regional differences appear (to different extent) on all varieties of the 'vertical' dialect-standardaxis, ranging from dialects over 'intermediate' varieties up to (written) standard varieties.

Linguistic complexity: The complex linguistic (syntactic-semantic) factors that influence the use of a GET passive show variation in (areal and social) space and thus make it possible to investigate its spreading grammaticalization synchronically.

High degree of dynamics: The indicated linguistic and extralinguistic dynamics of the phenomenon is reflected in the changes that can be documented over short periods of time.
Lay-linguistic relevance: Passive constructions are not the most salient object to inspire lay-linguistic discourse. Nonetheless, the use of the passive auxiliaries or their lexical origin are a frequent topic of meta-communicative discourse. ${ }^{20}$

\subsection{SFB DiÖ LPES on the analysis of the GET passive in Austria}

The LPE on German GET passives in Austria consists of five tasks that are used in a setting that aims to elicit the standard language (within the LPE-S) and the dialect (within the LPE-D), thus exposing every participant to 10 prompts. Within the framework of the complex surveys of project part 03 , at least 130 speakers in 13 locations in rural areas of Austria took part in the surveys. To ensure a uniform frame of reference, strict selection criteria were analyzed and defined for the survey locations: locations were selected which a) are small villages in rural areas and b) have enough speakers who fulfil the requisite socio-demographic criteria. Comparable to the SyHD project (in Hesse) and the SynBai (Syntax bairischer Dialekte 'Syntax of Bavarian Dialects') pilot study ${ }^{21}$, the research locations have populations of between 500 and 2,000 inhabitants. These locations are distributed across Austria (considering both the various federal states as well as the dialect geography of Austria; see Maps 1-4 below). The selection of speakers is directly linked to the central aim of the SFB DiÖ project part 03, namely gathering data on the variation and dynamics of the entire vertical spectrum of spoken German in each location, as well as of the individual spectra of linguistic possibility of its inhabitants. Consequently, the types of "autochthonous" speakers represented are as varied as possible, reflecting a broad range of variety competences and variation behavior (i.e., the most divergent "communities of practice," Eckert \& Rickford, 2001), which, when drawn together, in the inter-individual summary will portray the local variety spectrum of each location as authentically as possible. Because the hypothesis that language behavior and extralinguistic criteria in Austria are interconnected in a complex and regionally specific manner, the selection of speakers is based on extralinguistic criteria. $^{22}$ In the project, the social variables of age, gender, level of education, and - closely related to the latter-type of occupation (manual or communication-oriented), as well as "regional mobility" (depending on the commute between home and place of work) are applied and examined as selection criteria. ${ }^{23}$ One group of speakers (NORMs and NORFs) consists of individuals aged 60 and older who have spent their entire lives in the investigated location, most of them spent their working life either in said location or the immediate proximity in a manual profession, and are retired at the time of the interview. A second group of younger speakers, aged 18 to 35, displays more variation in terms of formal education, (regional) mobility and type of profession. For reasons of research practicability, the number of speakers has been restricted to 10 persons per location ( 2 older NORMs, 8 younger speakers, 4 with lower and 4 with higher level of formal education). In an ideal scenario, each of the 130 or more participants provides at least one relevant response to the experiment, providing a minimum of 1300 instances for a type-token analysis of the GET passive or other competing variants (650 each in LPE-S and LPE-D). The results presented in this article rely on data of 92 "autochthonous" participants from eight locations in Austria that represent five different dialect subareas (see Maps 1-4 below): East Central Bavarian (Allentsteig and Neumarkt/Ybbs, both Lower Austria, as well as Steyrling, Upper Austria), the Central-South Bavarian transition area (Neckenmarkt, Burgenland), South Bavarian (Tux, Tyrol, and Weißbriach, 


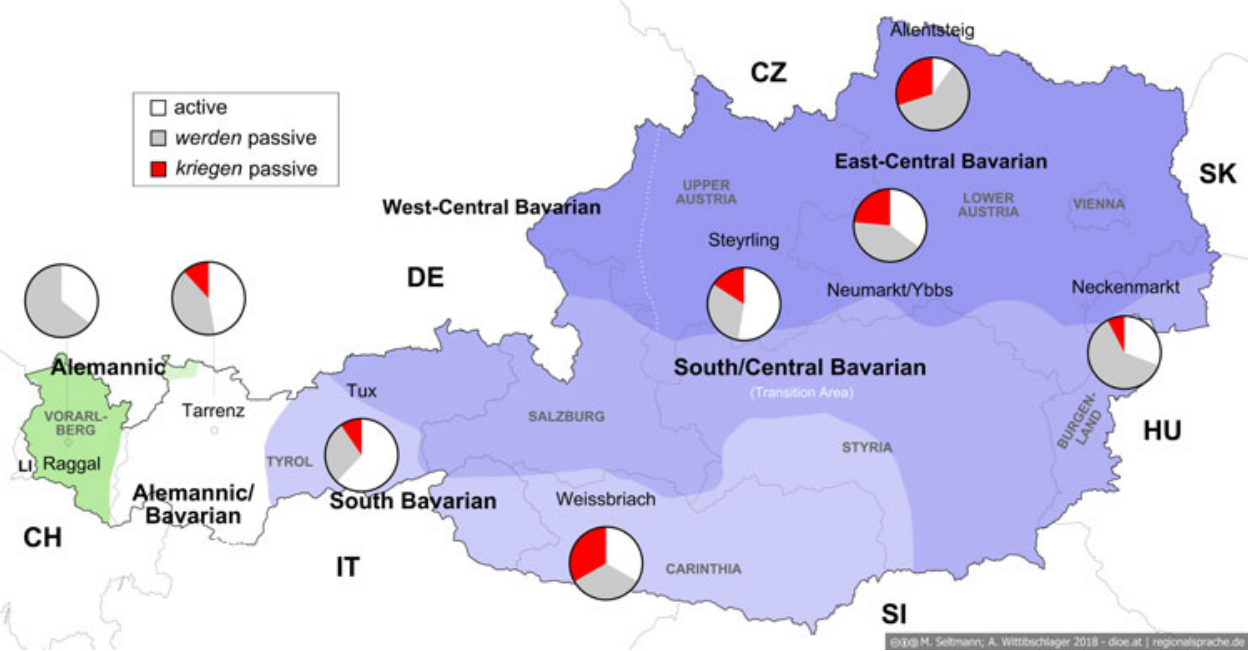

Map 1. Frequencies (in \%) of constructions in the LPE eliciting LPE-D by location, video stimulus "putting on glasses" (Allentsteig: $n=10 ;$ Neckenmarkt: $n=13 ;$ Neumarkt/Ybbs: $n=17$; Steyrling: $n=19$; Tarrenz: $n=17$; Tux: $n=21$; Weißbriach: $n=12$; Raggal: $n=14$ )

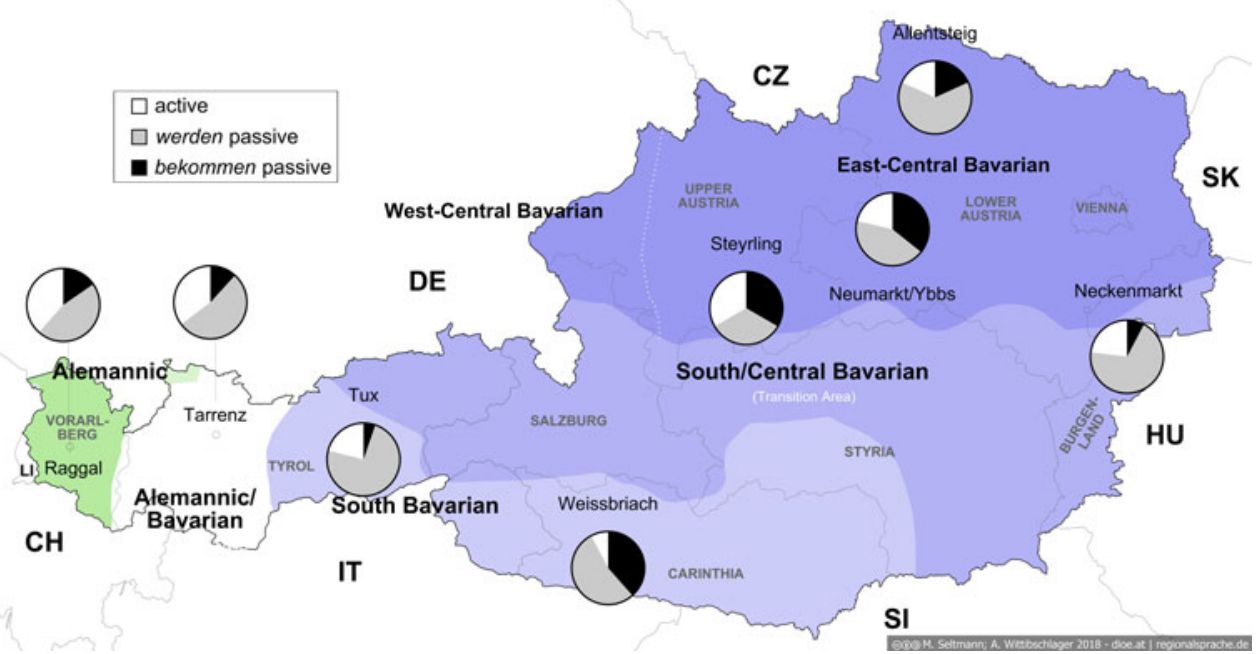

Map 2. Frequencies (in \%) of constructions in the LPE eliciting LPE-S by location, video stimulus "putting on glasses" (Allentsteig: $n=10 ;$ Neckenmarkt: $n=13$; Neumarkt/Ybbs: $n=14$; Steyrling: $n=15$; Tarrenz: $n=17$; Tux: $n=19$; Weißbriach: $n=13$; Raggal: $n=13$ )

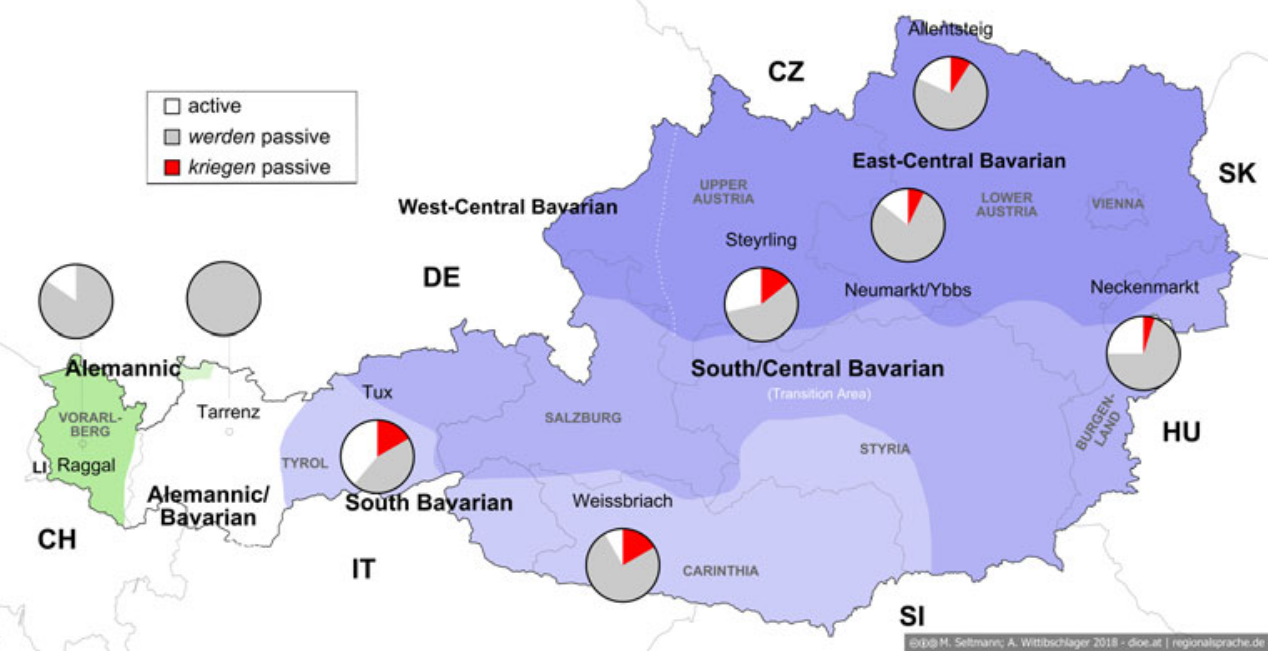

Map 3. Frequencies (in \%) of constructions in the LPE eliciting LPE-D by location, video stimulus "pulling tooth" (Allentsteig: $n=11 ;$ Neckenmarkt: $n=20$; Neumarkt/Ybbs: $n=14$; Steyrling: $n=14$; Tarrenz: $n=14$; Tux: $n=18$; Weißbriach: $n=12$; Raggal: $n=13$ ) 


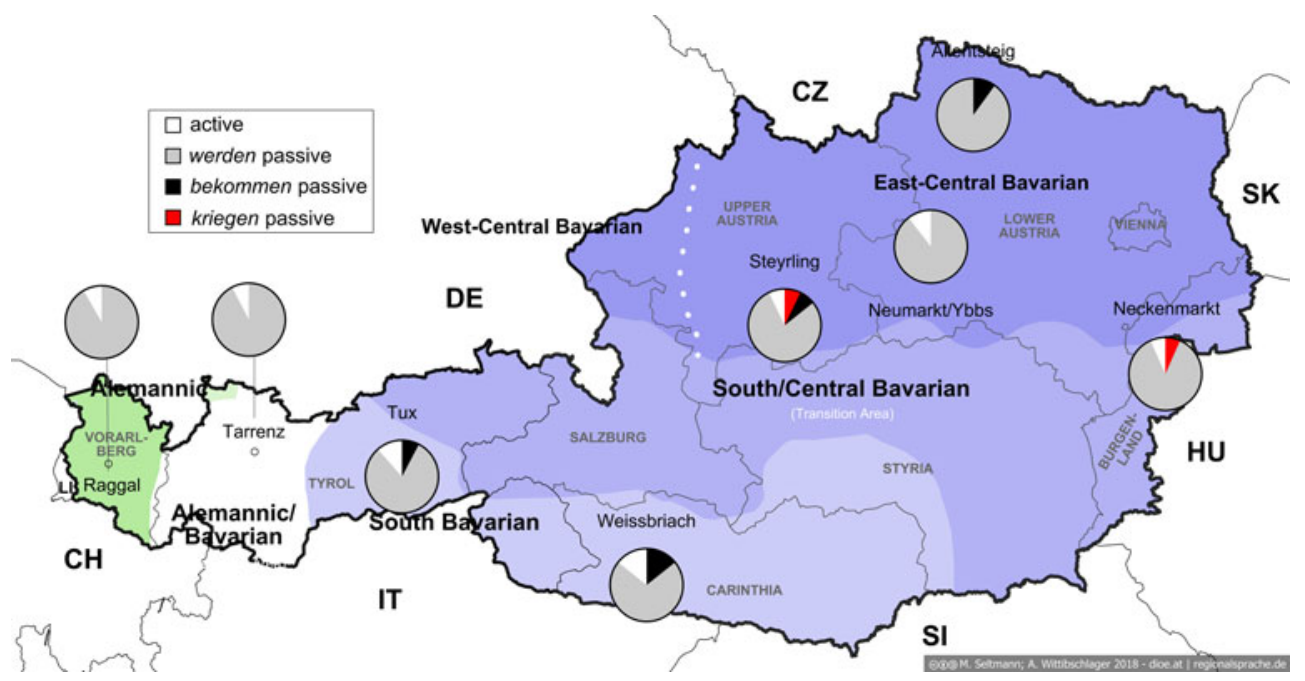

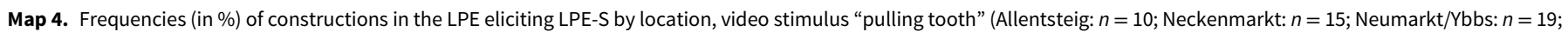
Steyrling: $n=14$; Tarrenz: $n=13$; Tux: $n=26$; Weißbriach: $n=14$; Raggal: $n=12$ )
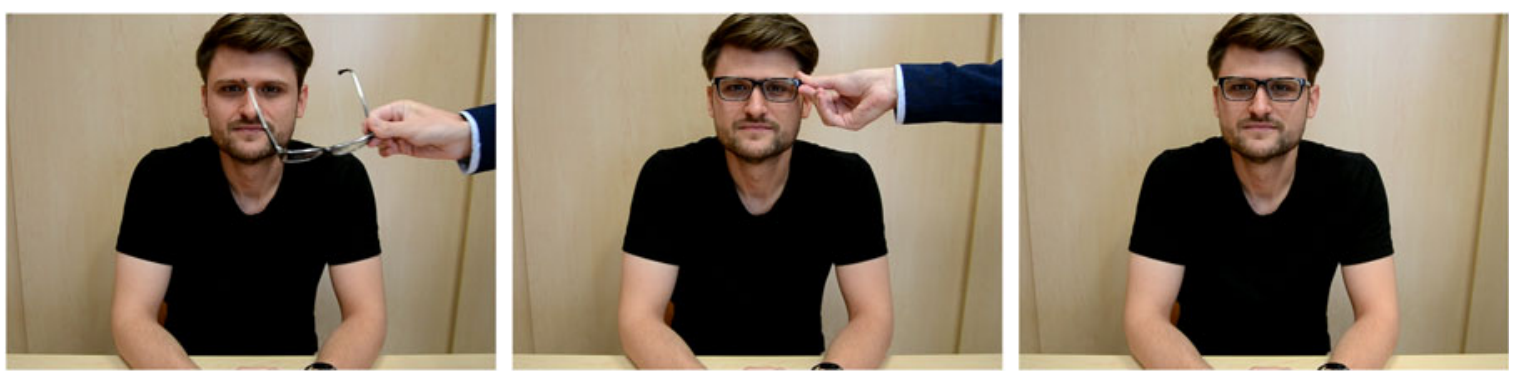

Figure 4. Example of the visual stimulus depicting the phenomenon group of the "GET passive" in the LPE. This is parallel to the auditive stimulus Was passiert mit dem Mann? ('What's happening to the man?').

Carinthia), the Alemannic-Bavarian transition area (Tarrenz, Tyrol), and Highest Alemannic (Raggal, Vorarlberg).

According to previous research, two linguistic factors that significantly influence the realization of a GET passive are the valency of the main verb and the semantic role of the subject's referent. The LPE (similar to Lenz, 2008, 2009) employs a video clip in every task. Each clip in a task set shows a (male) person in a situation where a particular action is performed on him: a tooth is pulled, a pair of glasses is put on his nose, his hair is cut, water is poured into a glass standing on the table in front of him, and a banana is taken from his hand. The main person therefore appears in different roles: as recipient of a transfer (with a neutral facial expression) by which water or glasses (re)enter his possession, as beneficiary receiving a haircut; as beneficiary of whom a tooth is extracted, which from his facial expression has a remedial effect and is appreciated; further, in the situation where he is bereft of the banana, he appears as a "maleficiary" who responds to the action by explicit discontent. In each situation, the person doing something to the main person is outside the frame of the video and only the agent's arms or hands are visible. The still images in Fig. 4 are taken from the video "putting on glasses" and exemplify the focus on the main person and the progression of the action. According to research, the GET passive in the Upper German area only appears in instances that reflect a lower degree of grammaticalization (i.e., with subject referent in the role of recipient or beneficiary). Instances with transitive verbs where the subject referent appears to be losing something ("maleficiary" of a privative act, i.e., an act of taking away sth. from so.) are rare. At this point, GET passives with intransitive dative verbs like helfen ('help') or mono-transitive verbs like schimpfen ('scold') do not appear to be part of Upper German varieties. For this reason, the videos only present actions that have a high potential of evoking transitive constructions: two giving actions (pouring water and putting on glasses), a cutting action, a pulling action, and a taking (away) action. Prior to the video, a recorded voice asks, "What's happening to the man?" (recorded either by an ORF-newscaster to elicit the standard language usage or a speaker of the participants local dialect to elicit the speaker's dialect), prompting the participant to respond. The expected answer is spontaneous and consists of a single, complete sentence. The definite wording of the question and the "hiding" of the agent aim to influence the theme-rhyme structure of the speaker's answer in the direction of a response that has the male main person as the subject referent in the topic position.

LPE Type: Open questions with video stimuli, without written text, with no narrative context and a low level of suggestion.

\subsection{Results of the GET passive LPES from the SFB DiÖ data}

The following section presents the first results from the data elicited using the LPEs. As previously mentioned, the data represents responses given by 92 participants ( 53 female, 39 male) from eight locations in Austria. 25 of the respondents represent an older generation ( $\varnothing 71.7$ years), 67 a younger generation ( $\varnothing 26.9$ years). The participants' answers contain 1,205 responses relevant to the 


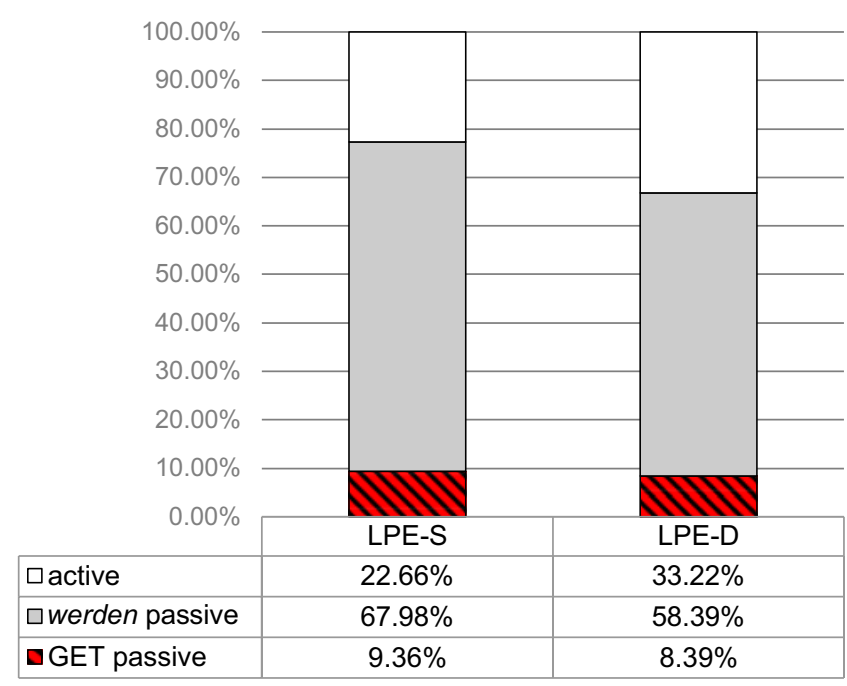

Figure 5. Frequencies (in \%) of constructions in the LPES (LPE-D: $n=596$, LPE-S: $n=609$ )

investigation of the GET passive, 596 of which occurred in LPE-D, 609 in LPE-S. These numbers relate to the productivity of the LPEs in terms of quantity. Relevance in this context is judged based on whether the participant's response to the stimulus question ('What's happening to the man?') captures the pictured frame and their description of the scene verbalizes the entities at the core of the frame. ${ }^{24}$ E.g., in the case of "putting on glasses," answers were considered relevant if they contained the glasses as a reference object and at the same time described an action of PUTTING (ON). In contrast, answers like Der ist beim Optiker. ('He's at the optometrist.') or Er probiert eine Brille. ('He tries on glasses.') were considered irrelevant. In situations where participants uttered irrelevant responses, the interviewer asked them to try a further response and replayed the video and accompanying stimulus question. Of the 103 instances where participants gave irrelevant responses in their first attempt, the interviewers' intervention provided relevant responses in 80 instances of the follow-up responses. The lowest number of relevant responses for a single respondent is nine, meaning that not a single participant gave only irrelevant answers. Even older participants, for which it was assumed that the length, complexity, and the unfamiliarity of the survey (of which the LPEs are only one part) could be problematic, produced an average of 13.8 relevant responses. The extent to which the participants gave relevant responses independently or only after the interviewer's intervention is considered as metadatum in the data preparation.

Fig. 5 shows the relative frequencies of variants the LPE produced in the two runs aiming at LPE-S and LPE-D. It considers the following three types of constructions:

- Active constructions: $41.30 \%$ of the active constructions in the LPE-S and $65.66 \%$ in the LPE-D responses contain an agentive subject. In these responses, the participants of the LPE predominantly realize the person in the center of the video as object of the action as in (5.1). If the main actor is realized as the subject, this is predominantly in the semantic role of recipient (as in (5.2), 46.38\% in LPE-S and 26.26\% in LPE-D). A further type of active construction involves lassen ('to let'), and perceives the subject referent as being in a passive role (6.52\% in LPE-S, $4.04 \%$ in LPE-D; cf. (5.3)). Other less frequent active constructions represent $5.80 \%$ (LPE-S) and $4.04 \%$ (LPE-D) of the instances.
- werden passive: As is the case with the active constructions, the werden passive is a category that contains different subcategories. In the majority of instances, the main actor, realized as the indirect object of the werden passive construction, predominantly appears in the Vorfeld (topic position (6.1); $90.51 \%$ in LPE-S, 95.81\% in LPE-D). Less frequently, the main person appears in the Mittelfeld (middle field (6.2); 9.49\% in LPE-S, 4,19\% in LPE-D).

- GET passives: The GET passives in Fig. 5 contain all GET passives regardless of the specific auxiliary used in the construction. In all instances, the main character appears topicalized in the Vorfeld of the utterance (cf. (4.1) and (4.2)).

(5) Examples for active constructions from the SFB DiÖ LPE

(5.1) Agent as subject referent Neumarkt/Ybbs-young)

the.DAT put someone.NOM a glasses.ACc.sG on

'Someone is putting glasses on him.'

(5.2) "Recipient" as subject referent

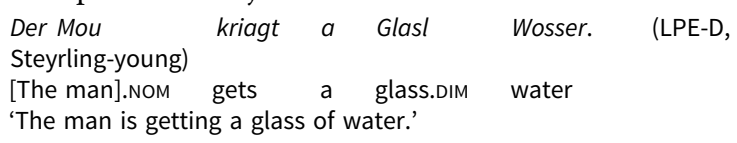

(5.3) lassen construction

Er lässt sich die Haare schneiden. (LPE-S,

He.Nom lets/allows himself the hair.PL cut.INF

'He is having his hair cut.'

(6) Examples for werden passive from the SFB DiÖ LPE

(6.1) "Recipient" as object in the Vorfeld

Ihm werden die Haare geschnitten. (LPE-S, Neckenmarktyoung)

He.DAT becomes the hair.PL cut

'His hair is being cut (for him).'

(6.2) "Recipient" (here: "loser"/maleficiary) as dative complement in the Mittelfeld

Die Banane wird ihm weggenommen. (LPE-S,

Neumarkt/Ybbs-old)

the banana becomes he.DAT away-taken

'The banana is stolen (from him).'

Fig. 5 indicates that the LPE produces primarily passive constructions in both LPE-D and LPE-S, as intended. Among these, the werden passive appears most frequently in both settings, i.e., the passive construction in which the main person is perceived as an indirect object (c.f. 6.1). Active constructions are less frequent but appear particularly in responses to the videos showing "putting on glasses" and "pouring water." Most of these active constructions contain the pattern Er kriegt/bekommt Wasser (in sein Glas). ("He gets water (in his glass)') or Er kriegt/bekommt eine Brille (auf die Nase). ('He gets glasses (on his nose).' cf. also (5.2)). Participants therefore use active constructions that offer advantages similar to those of passive constructions: These active constructions of the type "X gets $\mathrm{Y}$," like passive constructions in general, allow for a reduction of arguments (specifically, the omission of the agent referent), and-like GET passive constructions-allow the recipient to take the role of subject and appear in the Vorfeld as thematic focus (cf. Zifonun et al.,1997: 1849f.). Regarding the other prompts, these types of active constructions are either barely used or difficult to construct (e.g., Er bekommt Hilfe/einen Haarschnitt/*einen Bananenklau. 'He gets help/a haircut/*a banana-theft.'). ${ }^{25}$ 


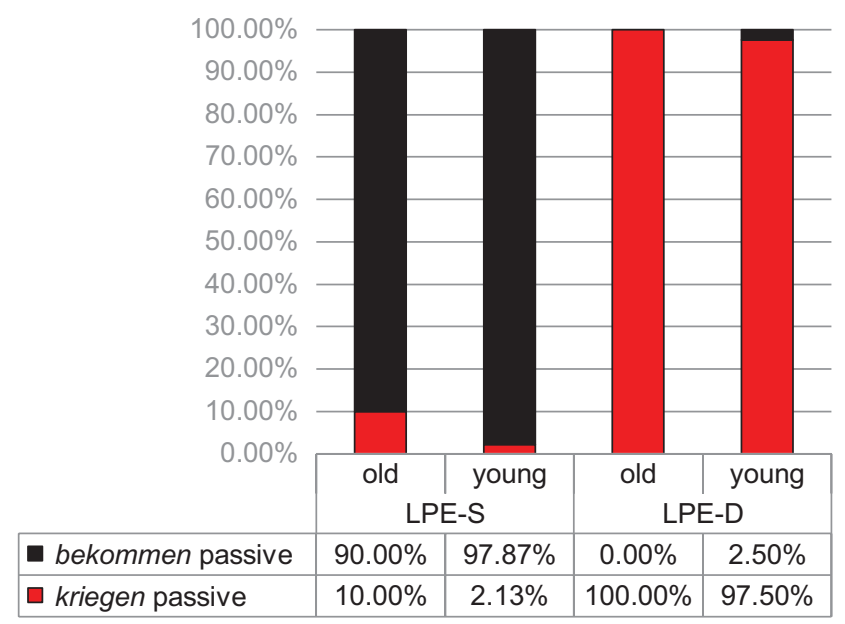

Figure 6. Frequencies (in \%) of the auxiliaries kriegen 'to get' and bekommen 'to get/ receive' in the GET-passive constructions of both speaker generations (old: $n=10$ (LPE-D) and $n=10$ (LPE-S); young: $n=40$ (LPE-D) and $n=47$ (LPE-S))

In addition to the active and werden passive constructions, the experiment also produced GET passive constructions. The frequencies in LPE-S and LPE-D are similar. This first glance at the data is notable: while the LPE shows a low frequency of GET passives, the data suggests that it is, at least to some degree, established in registers of spoken German closer to the standard and the dialects. Unlike previous research on the phenomenon, the LPE provides substantiated data on which constructions can be considered alternatives to the GET passive in situations that require the verbalization and perspectivization of the recipient of a ditransitive verb-action, and to what ratio these constructions are used. Fig. 6 offers a different and closer look at the data. It displays only the auxiliaries participants chose in their GET passive realizations and further distinguishes the younger and older speaker generations. Contrasting the different experiment settings reveals striking situational differences, primarily concerning the choice of passive auxiliary. The frequency of the GET passive appear to differ only slightly between speaker generations and LPE settings. The kriegen passive is dominant in the LPE-D (49 out of $50,98.0 \%$ ), while there is a strong preference for the bekommen passive in the LPE-S (55 out of 57, 96.5\%). Passives using erhalten at this point are not documented in the SFB DiÖ data. These findings are consistent with previous research on the vertical-social distribution of passive auxiliaries in the East Upper German language area and confirm the assumption that the methodological design of the LPE makes it possible to target aspects of distinct varieties. As Fig. 7 also indicates, younger speakers seem to produce higher frequencies of passive constructions (werden as well as GET passives) than the older generation.

To validate the observations, a statistical analysis of the data elicited through the LPEs is provided. While the experiments proved generally effective in eliciting descriptions of the actions in the video stimuli, there are instances where participants gave responses that strayed from the intended answers. In such instances, and to elicit information on alternative constructions, the interviewers frequently asked participants to provide further responses. This practice can influence the results of a quantitative analysis of the data. At the same time, excluding these additional answers and relying purely on the participants' first responses considerably reduces the available data: While the experiments elicited a total of 1,205 relevant responses across both settings, this number

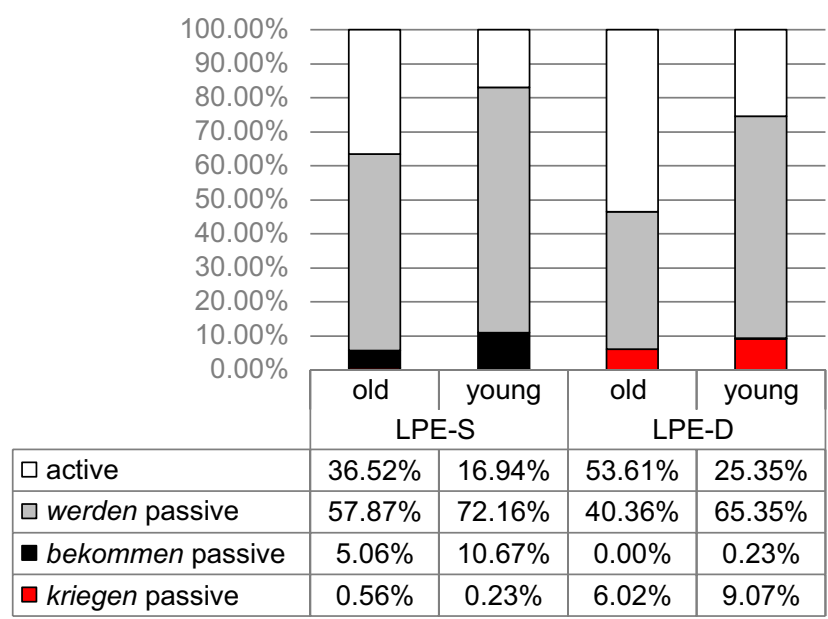

Figure 7. Frequencies (in \%) of constructions in both LPE settings by generation (old: $n=166$ (LPE-D) and $n=178$ (LPE-S); young: $n=430$ (LPE-D) and $n=431$ (LPE-S))

drops to 826 when only the first and spontaneous responses that were given without interference from the interviewer are considered. To address this, statistical analyses on both datasets were performed. The comparison of the results showed only slight differences between them. In the following section, the findings from the full dataset (1,205 responses) are discussed. When the results from the smaller dataset did not indicate an interpretation in the same order of magnitude, this is explicitly noted. To measure whether an observed difference between settings or participant groups is within the margins of probable results, if the variants were used to an equal extent, p-values based on the application of Fisher's Exact test are reported.

A comparison of all data from the experiments revealed a fundamental difference between the responses given in the LPE-D (dialect run) and in the LPE-S (standard run). While passive constructions (werden and GET passives taken together) are used more frequently than active constructions, there appear to be differences between both elicitation settings. Active constructions have a higher relative frequency $(\mathrm{p}<0.001)$ in the LPE-D (198 out of 596 responses, $33.2 \%$ ) than in the LPE-S (138 out of $609,22.6 \%$ ). A closer look at the older participants reveals that the difference between experiment settings is even more marked for this group. In the dialect run, active constructions are more frequent ( 89 out of $166,53.6 \%)$ than passive constructions, and thus markedly more frequent $(\mathrm{p}=0.002)$ than in the standard run, where only about a third of constructions are active (65 out of $178,36.5 \%){ }^{26}$ While the younger participants use active constructions less frequently than passive constructions in both settings, they appear more frequently $(\mathrm{p}=0.003)$ in the LPE-D (109 out of 430, $25.3 \%)$ than in the LPE-S (73 out of $430,16.0 \%) .{ }^{27}$ A direct comparison of the responses between older and younger participants in both runs confirms the difference between participant groups: Younger participants used passive constructions more frequently than older participants both in the LPE-D $(p<0.001)$ and the LPE-S $(p<0.001)$. The parallels between the results from the LPE and previous research clearly back the validity of the experimental settings used in the SFB DiÖ. Among the passive constructions, the GET passives are generally less frequent than the werden passives. However, in contrast to the general frequencies of passive constructions, the use of GET passives does not appear to be dependent on age. A comparison of the responses from both speaker generations shows that while older speakers appear to use GET 


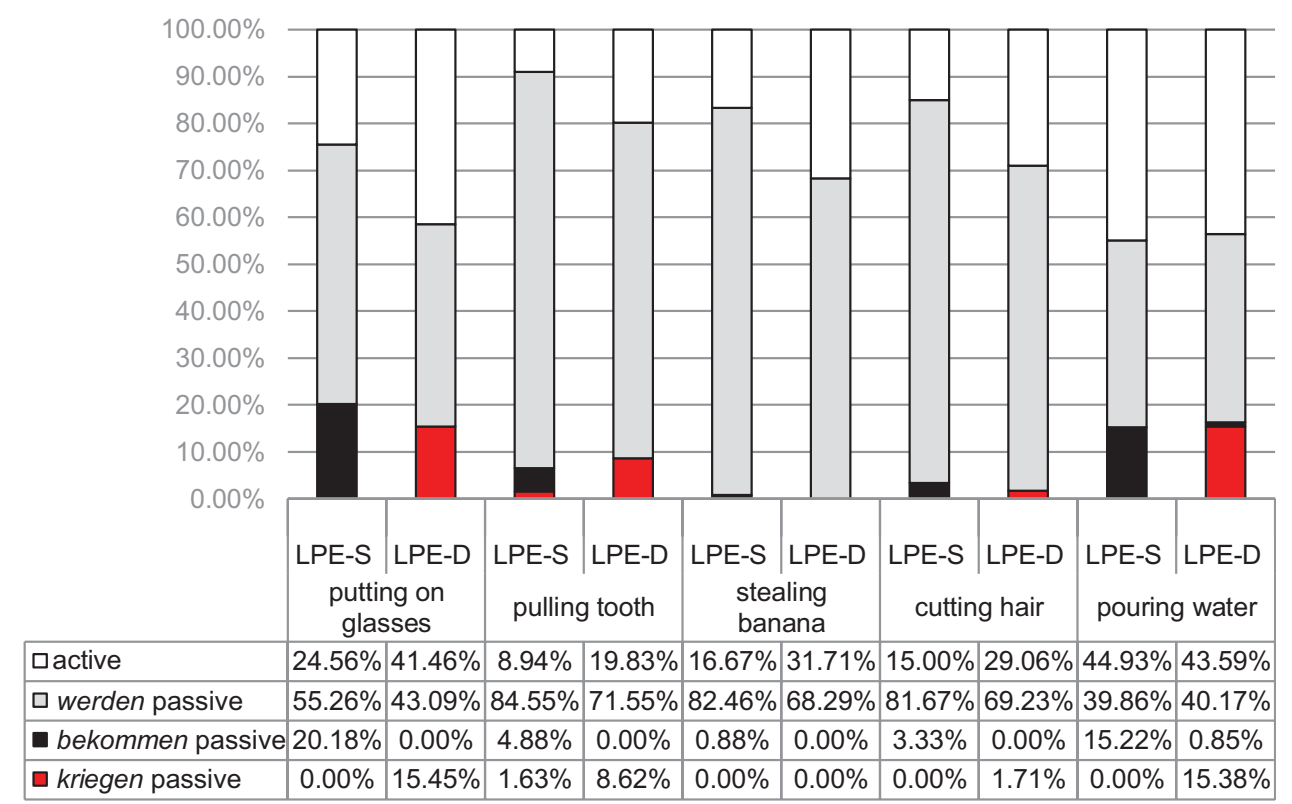

Figure 8. Frequencies (in \%) of constructions in both LPE settings by video stimulus ("putting on glasses": $n=114$ (LPE-S) and $n=123$ (LPE-D); "pulling tooth": $n=123$ (LPE-S) and $n=116$ (LPE-D); "stealing banana": $n=114$ (LPE-S) and $n=123$ (LPE-D); "cutting hair": $n=120$ (LPE-S) and $n=117$ (LPE-D); "pouring water": $n=138$ (LPE-S) and $n=117$ (LPE-D))

passive constructions slightly less frequently (10 out of $113,8.8 \%)$ than younger respondents ( 47 out of $348,13.5 \%)$, this difference is within the margin of probable results $(\mathrm{p}=0.2508)$. This similarity is even more pronounced in the intended dialect where the relative frequency of GET passives is similar $(\mathrm{p}=0.8502)$ between older ( 10 out of $77,13.0 \%$ ) and younger (40 out of $321,12.5 \%$ ) respondents. Across both participant groups, there is a strong preference for one or the other form of the GET passive (kriegen versus bekommen passive) that is dependent on the experiment setting $(\mathrm{p}<0.001)$.

Fig. 8 shows the results of the five distinct tasks in further detail within each setting and indicates the constructions used in the responses to every video. As mentioned above, the clips demonstrating "putting on glasses" and "pouring water" evoke particularly increased frequencies of active constructions, while the other three videos show these forms more rarely. At the same time, these two videos elicit the highest amount of GET passives (15.22\% to $20.18 \%$ ) in both LPE runs. These videos depict actions in which the main character takes the role of recipient, which ideally fits the GET passive (cf. above). The third and fourth most frequent are GET passives for the videos "pull tooth" (6.51\% to $8.62 \%)$ and "cut hair" (1.71\% to $3.3 \%)$. They suggest that the syntactic-semantic restrictions for the use of the GET passive are softening both in standard and non-standard varieties of Upper German. In comparison to the "cutting hair," the action "pulling tooth" is a transitive action in which a (direct) object is not only modified (like hairs that are being cut) but in which an entity is "leaving" the subject referent. Therefore, "pulling tooth" is semantically/conceptually an action which is closer to a prototypical act of transfer (a prototypical GET event) than an action of haircut. These semantic-conceptual differences are mirrored in the (at least slowly) divergent frequencies of GET passives evoked by these two videos. Only the video "steal banana" at this point has prompted only one isolated response that used a GET passive, shown in Fig. 8. Ditransitive verbs with privative semantics thus remain rare in Upper German varieties, both in registers close to the standard and in the dialects.
Application of a general linear mixed-effects model (Bates, Maechler, Bolker \& Walker, 2015) to the data that asks for the occurrence of GET passive constructions in dependence of the different stimuli, age groups, and experiment settings as fixed effects, and the participants as random effects, supports the observations on potential of the different stimuli to elicit GET passives and their competing variants. Further, the statistical analyses suggest that there are differences in the degree that the different stimuli elicit GET passive constructions. In comparison to the stimulus "putting on glasses," the category that was mapped onto the intercept, the stimulus "pouring water" did not show any significant difference $(\beta=0.214, \mathrm{SE}=0.351, \mathrm{z}=0.611, \mathrm{p}=0.541)$. However, the three other stimuli elicited GET passives to a significantly lower degree ("pulling tooth": $\beta=-1.863, \mathrm{SE}=0.391, \mathrm{z}=-4.770, \mathrm{p}<0.001$; "cutting hair": $\beta=-3.288, \mathrm{SE}=0.554, \mathrm{z}=-5.939 \mathrm{p}<0.001$; "stealing banana": $\beta=-5.311, \mathrm{SE}=1.141, \mathrm{z}=-4.656, \mathrm{p}<0.001$ ), supporting the hypothesis that the permissibility of the use of ditransitive verbs with privative semantics lags behind that of verbs with the subject referent appearing as the recipient or beneficiary of the action. These differences appear independent of the participants' age group or of the experimental setting. Overall, the results point to the productivity and validity of the used video stimuli in the LPEs. Results from further descriptions that require different verbs with different valency patterns would be desirable. However, considering the overall setup of the LPEs, in which the GET passive is only one of several phenomena addressed, and the greater context of the survey that includes an interview, a conversation among friends, and translation as well as reading tasks, it was not possible to include further tasks that aim at the GET passive.

In the next step, the regional distribution of the syntactic variants is used to illustrate to what extent the number and choice of locations indicates regional differences in the use of the GET passive across Austria. For this, the responses to the videos "putting on glasses" and "pulling tooth" are used. As shown in map 1-4, the LPEs evoked at least some instances of the GET passive both 


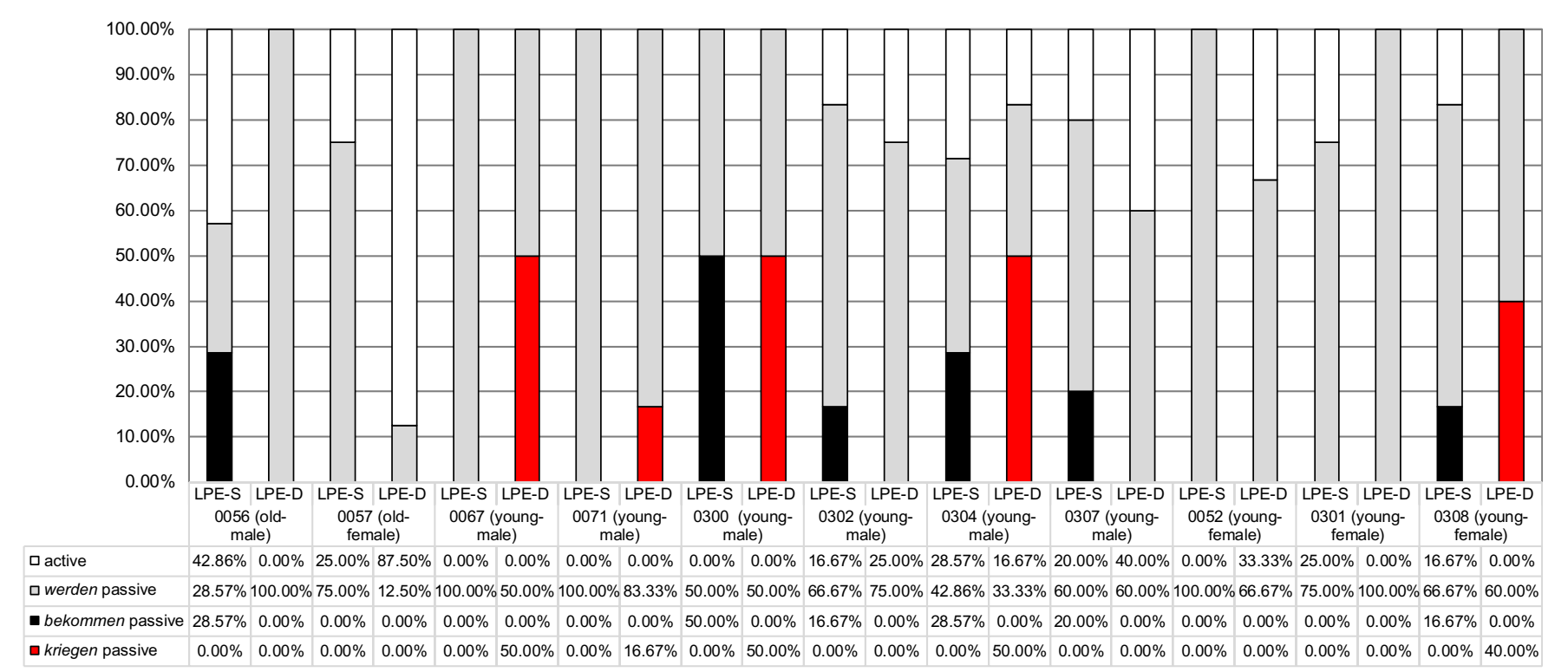

Figure 9. Individual frequencies (in \%) of constructions in the LPE-S and LPE-D in the South Bavarian locality of Weißbriach (11 speakers) all five video stimuli (old: $n=35$; young: $n=112$ )

in LPE-D and LPE-S in each of the investigated locations. These occurrences attest the arrival of the GET passive in all dialect areas of Austria, in standard and dialectal varieties. Only weak interregional differences appear. The comparison between the locations in the Bavarian dialect area on the one hand, and the Highest-Alemannic Raggal and Tarrenz in the BavarianAlemannic transition area on the other hand, is particularly interesting. In agreement with earlier research (Lenz, 2018a), the GET passive appears generally more frequent in the Bavarian area of Austria. It further supports the hypothesis that the GET passive has the strongest restrictions in Alemannic varieties: while some of the Alemannic-speaking respondents realize GET passives to describe a transfer in the direction of the subject referent ("putting on glasses"), there are no such responses to "pulling tooth." Lastly, the data from Raggal indicates that the GET passive is not rooted in the Alemannic dialect but enters the dialect "from above" by way of the standard variety (Lenz, 2013b). In all other locations, the GET passives appear both in LPE-S and LPE-D.

Application of a further general linear mixed effects model to the data requesting the occurrence of GET passive constructions in the participants' responses in dependence of the respondents age group and region (divided into three areas: Alemannic, Bavarian, and Alemannic-Bavarian transition area) as fixed effects and the speaker id and the stimulus as random effects did not indicate any significant regional differences in the use of the GET passive. This changed when the model considered only the participants' responses in the intended dialect. Based on this data, the data from the Bavarian region showed a significantly higher occurrence of GET passives $(\beta=3.373, \mathrm{SE}=1.667, \mathrm{z}=2.023, \mathrm{p}=0.043)$ in comparison to the data from the Alemannic area. The data from the Bavarian-Alemannic transition area in contrast did appear similar to the Alemannic data $(\beta=1.818, \mathrm{SE}=2.048, \mathrm{z}=0.888$, $\mathrm{p}=0.375) .{ }^{28}$ Age did not appear as a significant factor $(\beta=-0.178$, $\mathrm{SE}=1.059, \mathrm{z}=-0.168, \mathrm{p}=0.866)$.

As a final aspect, the intra-individual dimension of variation is considered. For this purpose, focus is concentrated on one selected survey location, i.e., Weißbriach in the South Bavarian area where eleven speakers took place in the LPE; two older informants and nine younger ones. Their frequencies of constructions are visualized in the situational comparison in Fig. 9 in which all five video stimuli are taken together. The diagram reveals divergent variation patterns across speakers and therefore different types of speakers:

1. There are speakers $(0057,0052,0301)$ who in both LPE runs (LPE-S and LPE-D) only produce werden passives besides less frequent active constructions, but none GET passives.

2. There are speakers $(0067,0071)$ who only in the dialect run (LPE-D) produce (some) GET passives which all represent kriegen ('to get') passives.

3. There are speakers $(0056,0302,0307)$ who only in the standard language context (LPE-S) produce (some) GET passives, which all represent bekommen ('to get/receive') passives.

4. Finally, there are speakers $(0300,0304,0308)$ who in both LPE runs (LPE-S and LPE-D) produce GET passives which primarily vary with werden ('to become') passives and less frequently with active constructions. The GET passives of these speakers contain the auxiliary kriegen ('to get') only in the LPE-D while they only produce bekommen ('to get/ receive') passives in the LPE-S.

To supplement Fig. 9, the Tables 2 and 3 show the distribution of the various construction types with respect to the individual speakers and the individual video stimuli. Together the results illustrate that the situational distribution of the GET passives, which can be observed across speakers and regions, is also evident intra-individually. In all speakers' variation repertoire, the kriegen passives seems to be subject to their dialect repertoires, while bekommen passives are part of their standard repertoire. Furthermore, implication relations which in synchrony can be drawn from the intra-individual variation patterns in Weißbriach can also be interpreted diachronically. These provide evidence for the chronological step of the grammaticalization pathways of the GET passive: Tables 2 and 3 reveal regarding the single video stimuli, particularly the actions "pouring water" and "putting on glasses" evoke GET passives. Only among those speakers who produce GET 
Table 2. Individual types of constructions in the LPE-D in the South Bavarian locations of Weißbriach (11 speakers) realized in all five video stimuli $(n=66)$

\begin{tabular}{|c|c|c|c|c|c|c|c|c|c|c|c|c|c|c|}
\hline \multirow[b]{2}{*}{ speaker } & \multicolumn{3}{|c|}{ Pouring water } & \multicolumn{3}{|c|}{$\begin{array}{l}\text { Putting on } \\
\text { glasses }\end{array}$} & \multicolumn{3}{|c|}{ Pulling tooth } & \multicolumn{3}{|c|}{ Cutting hair } & \multicolumn{2}{|c|}{$\begin{array}{l}\text { Stealing } \\
\text { banana }\end{array}$} \\
\hline & V1 & V2 & V3 & V1 & $\mathrm{V} 2$ & V3 & V1 & V2 & V3 & V1 & V2 & V3 & V1 & V2 V3 \\
\hline 0056 & & $x$ & & & $x$ & & & $x$ & & & $x$ & & & $x$ \\
\hline 0057 & $x$ & & & $x$ & & & $x$ & & & $x$ & & & & $x$ \\
\hline 0067 & & & $x$ & & & $x$ & & $x$ & $x$ & & $x$ & & & $x$ \\
\hline 0071 & & $x$ & $x$ & & $x$ & & & $x$ & & & $x$ & & & $x$ \\
\hline 0300 & & & x & & & x & & $x$ & & & $x$ & & & $x$ \\
\hline 0302 & $x$ & $x$ & & $x$ & $x$ & & & $x$ & & & $x$ & & & $x$ \\
\hline 0304 & & & $x$ & & & $x$ & & & $x$ & $x$ & $x$ & & & $x$ \\
\hline 0307 & $x$ & & & $x$ & & & & $x$ & & & $x$ & & & $x$ \\
\hline 0052 & & $x$ & & $x$ & & & & $x$ & & & $x$ & & $x$ & $x$ \\
\hline 0301 & & $x$ & & & $x$ & & & $x$ & & & $x$ & & & $x$ \\
\hline 0308 & & & $x$ & & & $x$ & & $x$ & & & $x$ & & & $x$ \\
\hline
\end{tabular}

$\mathrm{V} 1=$ active $\mid \mathrm{V} 2=$ werden passive $\mid \mathrm{V} 3=$ GET passive $($ red $=$ kriegen $)$

Table 3. Individual types of constructions in the LPE-S in the South Bavarian locations of Weißbriach (11 speakers) realized in all five video stimuli $(n=81)$

\begin{tabular}{|c|c|c|c|c|c|c|c|c|c|c|c|c|c|c|c|}
\hline \multirow[b]{2}{*}{ speaker } & \multicolumn{3}{|c|}{ Pouring water } & \multicolumn{3}{|c|}{$\begin{array}{l}\text { Putting on } \\
\text { glasses }\end{array}$} & \multicolumn{3}{|c|}{ Pulling tooth } & \multicolumn{3}{|c|}{ Cutting hair } & \multicolumn{3}{|c|}{$\begin{array}{l}\text { Stealing } \\
\text { banana }\end{array}$} \\
\hline & V1 & V2 & V3 & V1 & V2 & V3 & V1 & V2 & V3 & V1 & V2 & V3 & V1 & V2 & V3 \\
\hline 0056 & $x$ & $x$ & $x$ & & $x$ & & $x$ & & & & $x$ & & & $x$ & \\
\hline 0057 & $x$ & $x$ & & & $x$ & & & $x$ & & & $x$ & & & $x$ & \\
\hline 0067 & & $x$ & & & $x$ & & & $x$ & & & $x$ & & & $x$ & \\
\hline 0071 & & $x$ & & & $x$ & & & $x$ & & & $x$ & & & $\mathrm{x}$ & \\
\hline 0300 & & $x$ & $x$ & & $x$ & $x$ & & & $x$ & & $x$ & & & $x$ & \\
\hline 0302 & $x$ & $x$ & & & & $x$ & & $x$ & & & $x$ & & & $x$ & \\
\hline 0304 & $x$ & & $\mathrm{x}$ & & & $x$ & & $x$ & & & $x$ & & & $x$ & \\
\hline 0307 & $x$ & & & & & $x$ & & $x$ & & & $x$ & & & $x$ & \\
\hline 0052 & & $x$ & & & $x$ & & & $x$ & & & $x$ & & & $x$ & \\
\hline 0301 & $x$ & $x$ & & $x$ & $x$ & & & $x$ & & & $x$ & & $x$ & $x$ & \\
\hline 0308 & $x$ & $x$ & & & & $x$ & & $x$ & & & $x$ & & & $x$ & \\
\hline
\end{tabular}

$\mathrm{V} 1=$ active $\mid \mathrm{V} 2=$ werden passive $\mid \mathrm{V} 3=$ GET passive (green = bekommen)

passives with these video stimuli GET passives also occur with the action "pulling tooth" (but not vice versa). Weißbriach belongs to those locations where the experiments do not evoke GET passives with the other video stimuli ("cutting hair" and "stealing banana"). In summary, the Weißbriach example also shows the fruitfulness of an experimental approach w.r.t. the intra-individual variation dimension.

\section{Summary}

The intention of this article is to illustrate the potential, as well as the limitations, of computer supported "language production experiments" (LPEs) for the elicitation of data on syntactic variation within a large-scale project on areal linguistics. The context for the methodological reflection was the Special Research Programme (SFB) "German in Austria. Variation-Contact-Perception" in particular the project part 03 "Speech Repertoires and Varietal Spectra" that investigates vertical-social variation of autochthonous speakers of German in Austria in rural contexts. Regarding the investigation of the speakers' individual linguistic repertoires, the project uses various survey settings that target different registers of the speakers' individual varietal spectra and can be simultaneously compared between speakers. The LPEs discussed in this contribution are part of the (more) controlled survey settings used in the context of the SFB DiÖ to investigate syntactic variation specifically. The participants perform the LPEs in two runs to elicit syntactic data in both "intended standard" and "intended dialect." The LPEs are used to elicit different syntactic phenomena. We also proposed the setup of experiments of selected syntactic phenomenon complexes, which represent different subtypes within a classification of LPEs we also proposed here. To allow for a deeper reflection on the methodology, a case study of the data the LPE provided for German GET passives was provided. The analysis used data from 92 participants from eight locations that represent different linguistic areas of Austria. In every location, two groups of speakers are documented: an older generation of NORMs, contrasted with a younger generation of speakers with divergent sociodemographic criteria.

To summarize, the LPE's findings support the following hypotheses: Regarding quantity, the computer supported LPEs are a highly productive method for the elicitation of syntactic data regarding oral language use. Data from (more) open conversations are problematic as the syntactic phenomena (like the GET passive) occur in frequencies so low that they do not allow for the analysis of factors influencing or restricting the occurrence of the phenomenon. The LPEs provide a way to elicit a high number of instances of a particular syntactic phenomenon, and also enable researchers to control factors that influence the phenomenon. Because the setup of the experiment further enables researchers to keep semanticpragmatic factors constant, the LPEs allows researchers to identify further quantitative preferences between competing variants of a syntactic variable. This way, the LPE also helps to solve problems regarding the analysis of syntactic variables in practice. Conducting LPEs in two distinct runs enables researchers to elicit intra-individually distinct varieties of the speech repertoire of a speaker, while at the same time opening them for comparison. Although the LPEs are a complex and controlled method of data collection, they provide results that are comparable to those described in literature that rely on (more) free data from open conversations. Even speakers of the older generation investigated by the SFB DiÖ provide sufficient relevant data points for an intergenerational comparison. Relying on the apparent-time hypothesis allows for statements on language-dynamic tendencies. Finally, the parallels concerning intra- and interregional distribution of the GET passive between the findings from the LPEs in the SFB $\mathrm{DiO}$ and previous research support the hypothesis that the LPEs in the project can indicate interregional differences, despite the limited number of research locations. Thus, the LPE is overall a highly productive research method that provides solutions to the quantitative and qualitative problems of many other methodological approaches to syntactic variation. Particularly for the investigation of syntactic variation, in the SFB DiÖ, they substantially complement the results from (more) open conversations (cf. Section 3).

\section{PROJECTS (abbreviations and homepages)}

AdA-Altlas zur deutschen Alltagssprache—http://www.atlas-alltagssprache.de/

Bavarian Language Atlas-https://www.bayerische-landesbibliothek-online. de/speaking-linguistic-atlas-of-bavaria

Edisyn-European Dialect Syntax-http://www.dialectsyntax.org/

SADS—Syntaktischer Atlas der deutschen Schweiz—http://www.dialektsyntax. uzh.ch/de.html

SAND—Syntactische Atlas van de Nederlandse Dialecten—http://www. meertens.knaw.nl/sand/zoeken/index.php 
ScanDiaSyn—Scandinavian Dialect Syntax—http://websim.arkivert.uit.no/ scandiasyn/

SFB DiÖ_FWF Special Research Programme (SFB) 'German in Austria. Variation-Contact-Perception'-https://dioe.at/en/

SiSal—Siegerländer Sprachatlas—http://www.mundart.sisal.uni-siegen.de/ index.php

$\mathrm{SNiB}$-German Sprachatlas von Niederbayern-https://sprachatlasnie derbayern.bayerische-landesbibliothek-online.de/

SyHD—Syntax hessischer Dialekte—http://www.syhd.info/

SynAlm—Syntax des Alemannischen—https://cms.uni-konstanz.de/fileadmin/ archive/syntax-alemannisch/

SynBai-Syntax des Bairischen

Variantengrammatik des Deutschen—http://www.variantengrammatik.net/

Acknowledgments. This paper has benefited from comments and suggestions provided by Paul Kerswill, Nancy Niedzielski, Helmut Weiß, as well as two anonymous reviewers. Furthermore, Katharina Korecky-Kröll supported the quantitative analysis of the data. The research for this contribution was conducted in the frame of the SFB "German in Austria. Variation-ContactPerception" (FWF 060, principal investigator: Alexandra N. Lenz), funded by the Austrian Science Fund (FWF). The authors are grateful for this support.

\section{Notes}

1 This is a reference to, for example, ScanDiaSyn, SAND, SyHD and other dialect syntax projects, many of which have been combined in the network Edisyn (http://www.dialectsyntax.org/wiki/About_Edisyn).

2 For the discussion of syntactic quasi experiments of the type mentioned here, cf. Ahlers, 2018; Breuer, 2016, 2017a, 2017b; Flecken, 2010; Kallenborn, 2011, 2016; Lenz, 2008, 2016, 2017. For a more general methodological discussion of experimental methods in linguistics, cf. also Abbuhl, Gass \& Mackey, 2013; Breuer \& Bülow, 2019; Campbell \& Stanley, 1963; Gilquin \& Gries, 2009; Kristiansen, 2010.

3 It is supported as a Special Research Programme (SFB F060) by the Austrian Science Funds (FWF). The first funding period is from 2016 to 2019. For further details cf. Budin, Elspaß, Lenz, Newerkla \& Ziegler, 2019; Lenz, 2018b. See also the project homepage: https://www.dioe.at/en/

4 http://www.dialektsyntax.uzh.ch/de.html

5 http://www.syhd.info

$6 \mathrm{https} / / / \mathrm{cms}$.uni-konstanz.de/fileadmin/archive/syntax-alemannisch/

$7 \mathrm{http}: / /$ www.mundart.sisal.uni-siegen.de/

$8 \mathrm{http}: / /$ www.atlas-alltagssprache.de/

$9 \mathrm{http}: / /$ www.variantengrammatik.net/index.html

10 Online data collection was or is also used in the SynBai pilot study (cf. Lenz et al., 2015) and in the AdA.

11 Projects that employ a combination of written and oral data collection are e.g., ScanDiaSyn and SyHD.

12 Of course, language production experiments do not have to be restricted to spoken data. See Lenz, 2009 with regard to an LPE on GET passives in the written standard of German, Dutch and Luxembourgish students.

13 For example, in the tasks aiming at the GET passive (cf. Section 4), two different actors are used for the LPE-S and the LPE-D, but the depicted activities are the same.

$14 \mathrm{http} / / /$ osdoc.cogsci.nl/

15 All tasks aim at evoking one sentence or a part of a sentence, but especially the question tasks differ in their openness.

16 For the sake of a clear illustration, we suggest a practical working scale from "1" ('not very suggestive') to " 3 " ('very suggestive') for the SFB DiÖ tasks, indicating how much influence each task has on the given answer.

17 A reviewer pointed to the relevance of the so-called DP hypothesis in the context of the question whether infinitival constructions are verbal or nominal. The hypothesis is concerned with parallels between the structure of DP and CP (cf. e.g., Bernstein, 2001). In front of this theoretical background, the question of whether infinitival constructions are verbal or nominal may be less important. 18 Here a selection of relevant references: Abraham, 1985, 1991; Askedal, 1984, 2005; Cook, 2006; Diedrichsen, 2008, 2012; Eroms, 1978, 2000; Glaser, 2005; Kasper, 2017; Leirbukt, 1997; Lenz, 2007, 2008, 2009, 2012, 2013b, 2017, 2018a; Molnárfi, 1998; Teuber, 2005: 84ff.; Zifonun et al., 1997: 1824ff.
19 This headline illustrates the advent of the erhalten passive in Austrian written standard German: „Nationalbibliothek erhält Nachlass von Gerhard Bronner geschenkt" ("National Library gets estate of Gerhard Bronner donated'). (http://wien.orf.at/news/stories/2678164/ (26 September, 2018).

20 Consider e.g., the examples taken from message boards in Lenz (2013a: 406-417).

21 See <www.syhd.info> and Lenz et al., 2015.

22 The expectation underlying this modus operandi is not that socially homogenous groups with clearly definable varieties and homogenous language behaviour will be found via the extralinguistic criteria. The anticipation is simply that, in divergent demographic groups, there will be speakers whose language behaviour (more or less) clearly differs from (more or fewer) speakers in neighbouring groups. Cf. Lenz, 2006 for the German language area.

23 See Bellmann (1994: 39f.) [emphasis A. N. L.]: "in the dialect areas of West Middle German, a difference in age would [...] mostly not suffice as the sole criterion to differentiate between a significantly 'older' and a 'younger' dialect. This may also apply to other dialect areas, such as the Bavarian dialect area. 'This much is clear: Younger forms are not necessarily restricted to younger speakers and, conversely, that older versions of the local dialect are not used solely by the oldest speakers.' (Tatzreiter, 1989: 167)" [own translation].

24 "A word's meaning can be understood only with reference to a structured background of experience, beliefs, or practices, constituting a kind of conceptual prerequisite for understanding the meaning. Speakers can be said to know the meaning of the word only by first understanding the background frames that motivate the concept that the word encodes. Within such an approach, words or word senses are not related to each other directly, word to word, but only by way of their links to common background frames and indications of the manner in which their meanings highlight particular elements of such frames." (Fillmore \& Atkins, 1992: 76f.)

25 There is no areal concentration of these active constructions of the type "X gets Y" (with a recipient role in the subject function), they occur (even in low frequencies) in all our survey locations.

26 The pattern generally holds when considering only the participants' first responses, albeit to a lesser extent $(\mathrm{p}=0.01)$. The older participants still use more active constructions than passive constructions in the intended dialect (54 out of 102, 53.9\%) than in the intended standard (33 out of 96, 34.4\%). 27 As with the older participants, the difference becomes less marked when considering only younger participants' first responses, who use active constructions less frequent both in the intended dialect (253 out of 325, 77.8\%) and the intended standard ( 257 out of $303,84.8 \%$ ), yet it remains significant if judged by its $\mathrm{p}$-value $(\mathrm{p}=0.032)$

28 When considering only participant's first responses, the model finds no significant differences between the different regions. This may be due to a too small number of GET passives in participants' first responses.

\section{References}

Abbuhl, Rebekha, Susan Gass \& Alison Mackey. 2013. Experimental research design. In Robert J. Podesva \& Devyani Sharma (eds.), Research methods in linguistics, 116-134. Cambridge: Cambridge University Press.

Abraham, Werner. 1985. Grammatik von kriegen und bekommen. Osnabrücker Beiträge zur Sprachtheorie 30. 142-165.

Abraham, Werner. 1991. Aktionsartsemantik und Auxiliarisierung im Deutschen. In Elisabeth Feldbusch, Reiner Pogarell \& Cornelia Weiss (eds.), Neue Fragen der Linguistik: Akten des 25. Linguistischen Kolloquiums, Paderborn 1990, Band I: Bestand und Entwicklung (Linguistische Arbeiten), vol. 270, 125-133. Tübingen: Niemeyer.

Abraham, Werner \& Josef Bayer. 1993. Dialektsyntax (Linguistische Berichte: Sonderheft 5). Opladen: Westdt. Verl.

Ahlers, Timo. 2018. Varietäten und ihr Kontakt kognitiv: Syntaktische Perzeptions- und Produktionsprozesse bei norddeutschen Zuwanderern in Österreich. Wien: University of Vienna PhD thesis.

Askedal, John Ole. 1984. Zum kontrastiven Vergleich des sogenannten „bekommen / erhalten / kriegen-Passivs"im Deutschen und entsprechender norwegischer Fügung aus fă und dem Partizip Perfekt. Norsk Lingvistik Tidsskrift 2. 133-166.

Askedal, John Ole. 2005. Grammatikalisierung und Persistenz im deutschen „Rezipientenpassiv“ mit bekommen / kriegen / erhalten. In 
Torsten Leuschner, Tanja Mortelmans \& Sarah de Groodt (eds.), Grammatikalisierung im Deutschen, 211-228. Berlin: de Gruyter.

Auer, Peter. 2005. Europe's sociolinguistic unity, or: A typology of European dialect/standard constellations. In Nicole Delbecque, Johan van der Auwera \& Dirk Geeraerts (eds.), Perspectives on variation. Sociolinguistic, historical, comparative, 69-92. Berlin: de Gruyter.

Barbiers, Sjef. 2005. De Syntactische Atlas van de Nederlandse Dialecten. Taal en tongual 18. 7-40.

Barbiers, Sjef, Johan van der Auwera, Hans Bennis, Eefje Boef, Gunther de Vogelaer \& Margreet van der Ham. 2008. SAND: Syntactische atlas van de Nederlandse dialecten. Deel II. Amsterdam: Amsterdam UP.

Bates, Douglas, Martin Maechler, Ben Bolker \& Steve Walker. 2015. Fitting linear mixed-effects models using lme4. Journal of Statistical Software 67(1). 1-48.

Bayer, Josef. 1984. COMP in Bavarian syntax. The Linguistic Review 3(3). 209-274.

Bayer, Josef. 1993. Zum in Bavarian and scrambling. In Werner Abraham \& Josef Bayer (eds.), Dialektsyntax (Linguistische Berichte, Special Issue 5), 50-70. Opladen: Westdeutscher Verlag.

Bayer, Josef \& Ellen Brandner. 2008. Wie oberflächlich ist die syntaktische Variation zwischen Dialekten?: Doubly-filled COMP revisited. In Franz Patocka \& Guido Seiler (eds.), Dialektale Morphologie, dialektale Syntax: Beiträge zum 2. Kongress der Internationalen Gesellschaft für Dialektologie des Deutschen, Wien, 20. - 23. September 2006, 9-26. Wien: Praesens.

Bellmann, Günter. 1994. Mittelrheinischer Sprachatlas: (MRhSA). Tübingen: Niemeyer.

Bernstein, Judy B. 2001. The DP Hypothesis: Identifying clausal properties in the nominal domain. In Mark Baltin \& Chris Collins (eds.), The handbook of contemporary syntactic theory, 536-561. Malden: Blackwell.

Breuer, Ludwig Maximilian. 2016. Methoden städtischer Regionalsprachenforschung: Wiener Variation des Relativsatzanschlusses im Online-Fragebogen. In Alexandra N. Lenz \& Franz Patocka (eds.), Syntaktische Variation: Areallinguistische Perspektiven (Wiener Arbeiten zur Linguistik 2), 219-248. Göttingen: Vienna University Press.

Breuer, Ludwig Maximilian. 2017a. Computers \& Coffee: Computergestützte Sprachproduktionstests zur syntaktischen Variation des „unbestimmten Artikels vor Massennomen“ im „Wienerischen“. In Helmut Kowar (ed.), International Forum on Audio-Visual Research (Jahrbuch des Phonogrammarchivs 7), 86-111. Wien: VÖAW.

Breuer, Ludwig Maximilian. 2017b. Wien, das was anders ist? RelativsatzAnschluss in einem spontansprachlichen "Wiener" Korpus. In Alexandra N. Lenz, Ludwig Maximilian Breuer, Tim Kallenborn, Peter Ernst, Manfred Michael Glauninger \& Franz Patocka (eds.), Bayerischösterreichische Varietäten zu Beginn des 21. Jahrhunderts-Dynamik, Struktur, Funktion, 177-198. Stuttgart: Franz Steiner.

Breuer, Ludwig Maximilian \& Lars Bülow. 2019. Experimental approaches in the realm of language variation: How language production tests can help us to better understand language variation. In Lars Bülow, Ann-Kathrin Fischer \& Kristina Herbert (eds.), Dimensions of linguistic space: Variation-multilingualism-conceptualisations/Dimensionen des sprachlichen Raums: Variation - Mehrsprachigkeit - Konzeptualisierung (Schriften zur Deutschen Sprache in Österreich 45), 251-269. Wien: Lang.

Budin, Gerhard, Stephan Elspaß, Alexandra N. Lenz, Stefan M. Newerkla \& Arne Ziegler. 2019. The research project "German in Austria. VariationContact-Perception." In Lars Bülow, Ann-Kathrin Fischer \& Kristina Herbert (eds.), Dimensions of linguistic space: Variation-multilingualismconceptualisations/Dimensionen des sprachlichen Raums. Variation Mehrsprachigkeit - Konzeptualisierung (Schriften zur Deutschen Sprache in Österreich 45), 7-35. Wien: Lang.

Campbell, Donald T. \& Julian C. Stanley. 1966. Experimental and quasi-experimental designs for research. Chicago: Rand-McNally.

Cheshire, Jenny. 2005. Syntactic variation and beyond: Gender and social class variation in the use of discourse-new markers. Journal of Sociolinguistics 9(4). 479-508.

Cook, Philippa. 2006. The datives that aren't born equal: Beneficiaries and the dative passive. In Daniel Hole, André Meinunger \& Werner Abraham (eds.), Datives and other cases: Between argument structure and event structure, 141-184. Amsterdam \& Philadelphia: John Benjamins.
Cornips, Leonie \& Cecilia Poletto. 2005. On standardising syntactic elicitation techniques (part 1). Lingua 115(7). 939-957.

Demske, Ulrike. 2011. Finale Marker in Infinitivkonstruktionen - Wandel und Variation. In Helen Christen, Franz Patocka \& Evelyn Ziegler (eds.), Struktur, Gebrauch und Wahrnehmung von Dialekt. Beitrage zum 3. Kongress der Internationalen Gesellschaft für Dialektologie des Deutschen (IGDD), Zürich, 7.-9. September 2009, 29-46. Wien: Praesens.

Diedrichsen, Elke. 2008. The grammaticalization of the bekommen-passive in a RRG-perspective. In Rolf Kailuweit, Björn Wiemer, Eva Staudinger \& Ranko Matasović (eds.), New applications of role and reference grammar: Diachrony, grammaticalization, romance languages, 87-145. Cambridge: Cambridge Scholars Publishing.

Diedrichsen, Elke. 2012. What you give is what you GET? On reanalysis, semantic extension and functional motivation with the German Bekommen-passive construction. Linguistics 50(6). 1163-1204.

Donhauser, Karin. 1989. Die Infinitivkonstruktion mit z' und zum im Bairischen. In Erwin Koller, Werner Wegstein \& Richard Wolf (eds.), Bayrisch-österreichische Dialektforschung (Würzburger Beiträge Zur Deutschen Philologie), vol. 1, 291-304. Würzburg: Königshausen + Neumann.

Eckert, Penelope \& John R. Rickford. 2001. Style and sociolinguistic variation. Cambridge: Cambridge University Press.

Eroms, Hans-Werner. 1978. Zur Konversion der Dativphrasen. Sprachwissenschaft 3. 357-405.

Eroms, Hans-Werner. 2000. Syntax der deutschen Sprache (de Gruyter Studienbuch). Berlin: de Gruyter.

Eroms, Hans-Werner \& Rosemarie Spannbauer-Pollmann (eds). 2006. Bayerischer Sprachatlas / Regionalteil V: Sprachatlas von Niederbayern (SNiB). Band 1: Einführung mit Syntaxauswertung. Heidelberg: Winter.

Fillmore, Charles J. \& Beryl T. Atkins. 1992. Toward a frame-based lexicon: The semantics of RISK and its neighbours. In Adrienne Lehrer \& Eva F. Kittay (eds.), Frames, fields and contrasts: New essays in semantic and lexical organization, 75-102. Hillsdale: Erlbaum.

Fingerhuth, Matthias \& Ludwig M. Breuer. accepted. Language production experiments as tools for corpus construction. A contrastive study of complementizer agreement and doubly-filled COMP. Corpus Linguistics and Linguistic Theory.

Fingerhuth, Matthias \& Alexandra N. Lenz. accepted. Variation and change of "complementizer agreement" in German. Analyses from the Austrian language area. Linguistic Variation.

Flecken, Monique. 2010. Event conceptualization in language production of early bilinguals. Heidelberg \& Nijmegen: University of Heidelberg \& Radboud University of Nijmege PhD thesis.

Fleischer, Jürg. 2002. Die Syntax von Pronominaladverbien in den Dialekten des Deutschen: eine Untersuchung zu Preposition Stranding und verwandten Phänomenen (Zeitschrift für Dialektologie und Linguistik - Beihefte 123). Stuttgart: Franz Steiner.

Fleischer, Jürg, Simon Kasper \& Alexandra N. Lenz. 2012. Die Erhebung syntaktischer Phänomene durch die indirekte Methode: Ergebnisse und Erfahrungen aus dem Forschungsprojekt "Syntax hessischer Dialekte" (SyHD). Zeitschrift für Dialektologie und Linguistik 79(1). 1-42.

Fleischer, Jürg, Alexandra N. Lenz \& Helmut Weiß. 2015. Syntax hessischer Dialekte (SyHD). In Roland Kehrein, Alfred Lameli \& Stefan Rabanus (eds.), Regionale Variation des Deutschen - Projekte und Perspektiven, 261-288. Berlin \& New York: de Gruyter.

Fuß, Eric. 2008. Multiple agreement and the representation of inflection in the C-domain. Linguistische Berichte 213. 77-106.

Gilquin, Gaëtanelle \& Stefan T. Gries. 2009. Corpora and experimental methods: A state-of-the-art review. Corpus Linguistics and Linguistic Theory 5(1). 1-26.

Glaser, Elvira. 2005. Krieg und kriegen: zur Arealität der BEKOMMENPeriphrasen. In Ulla Kleinberger Günther, Annelies Häcki Buhofer \& Elisabeth Piirainen (eds.), "Krieg und Frieden"- Auseinandersetzung und Versöhnung in Diskursen, 43-64. Tübingen: Francke.

Grewendorf, Günther \& Helmut Weiß. 2014. Bavarian syntax: Contributions to the theory of syntax (Linguistik Aktuell/Linguistics Today 220). Philadelphia: John Benjamins. 
Gruber, Bettina. 2008. Complementiser agreement - New evidence from the Upper Austrian variant of Gmunden. Wien: University of Vienna Master thesis.

Haider, Hubert. 1993. Deutsche syntax - generativ: Vorstudien zur Theorie einer projektiven Grammatik (Tübinger Beiträge zur Linguistik 325). Tübingen: Narr.

Henn-Memmesheimer, Beate. 1986. Nonstandardmuster: ihre Beschreibung in der Syntax und das Problem ihrer Arealität (Reihe Germanistische Linguistik 66). Tübingen: Niemeyer.

Kallenborn, Tim. 2011. Ein experimenteller Ansatz zur Erhebung regionalsprachlicher Syntaxdaten. In Brigitte Ganswind (ed.), Perspektiven der Variationslinguistik: Beiträge aus dem Forum Sprachvariation, 279-304. Hildesheim, Zürich \& New York: Olms.

Kallenborn, Tim. 2016. Regionalsprachliche Syntax: Horizontal-vertikale Variation im Moselfränkischen. Wien: University of Vienna PhD thesis.

Kallulli, Dalina \& Antonia Rothmayr. 2008. The syntax and semantics of indefinite determiner doubling constructions in varieties of German. The Journal of Comparative Germanic Linguistics 11(2). 95-136.

Kasper, Simon. 2017. Passiv, Possession und Belebtheit. SyHD-atlas. http:// www.syhd.info/apps/atlas/\#passiv-possession-und-belebtheit (5 December 2017).

Kayne, Richard S. 1996. Microparametric syntax: Some introductory remarks. In James R. Black \& Virginia Motapanyane (eds.), Microparametric syntax and dialect variation, ix-xviii. Philadelphia: John Benjamins.

Kristiansen, Tore. 2010. Investigation of language in space: Experimental techniques. In Peter Auer \& Jürgen Erich Schmidt (eds.), Language and space: An International handbook of linguistic variation, vol. I: Theories and Methods, 528-549. New York: de Gruyter.

Labov, William. 1978. Crossing the gulf between sociology and linguistics. The American Sociologist 13(2). 93-103.

Larsson, Ida. 2014. Double complementizers. Nordic Atlas of Language Structures (NALS) 1. 447-457.

Lavandera, Beatriz R. 1978. Where does the sociolinguistic variable stop? Language in Society 7. 171-82.

Leirbukt, Oddleif. 1997. Untersuchungen zum bekommen-Passiv im heutigen Deutsch (Germanistische Linguistik 177). Tübingen: Niemeyer.

Lenz, Alexandra N. 2007. Zur variationslinguistischen Analyse regionalsprachlicher Korpora. In Werner Kallmeyer \& Gisela Zifonun (eds.), Sprachkorpora - Datenmengen und Erkenntnisfortschritt (Jahrbuch des Instituts für Deutsche Sprache 2006), 169-202. Berlin \& Boston: de Gruyter.

Lenz, Alexandra N. 2008. Wenn einer etwas gegeben bekommt. In Franz Patocka (ed.), Dialektale morphologie, dialektale syntax: Beiträge zum 2. Kongress der Internationalen Gesellschaft für Dialektologie des Deutschen; Wien, 20. - 23. September 2006, 157-180. Wien: Praesens.

Lenz, Alexandra N. 2009. On the perspectivization of a recipient role: Crosslinguistic results from a speech production experiment on GET-passives in German, Dutch and Luxembourgish. Groninger Arbeiten zur Germanistischen Linguistik 49. 125-144.

Lenz, Alexandra N. 2010. Emergence of varieties through restructuring and reevaluation. In Peter Auer \& Jürgen Erich Schmidt (eds.), Language and space: An international handbook of linguistic variation, vol 1: Theories and Methods, 295-315. Berlin \& New York: de Gruyter.

Lenz, Alexandra N. 2012. On the genesis of the German recipient passive: Two competing hypotheses in the light of current dialect data. In Gunther de Vogelaer \& Guido Seiler (eds.), The dialect laboratory. Dialects as a testing ground for theories of language change, 121-138. Philadelphia: John Benjamins.

Lenz, Alexandra N. 2013a. Three "competing" auxiliaries of a non-canonical passive: On the German GET passive and its auxiliaries. In Artemis Alexiadou \& Florian Schäfer (eds.), Non-canonical passives, 63-94. Philadelphia: John Benjamins.

Lenz, Alexandra N. 2013b. Vom ^kriegen « und >bekommen«: Kognitiv-semantische, variationslinguistische und sprachgeschichtliche Perspektiven (Linguistik - Impulse \& Tendenzen 53). Berlin: de Gruyter.

Lenz, Alexandra N. 2016. On eliciting dialect-syntactic data: Comparing direct and indirect methods. In Augustin Speyer \& Philipp Rauth (eds.), Syntax aus Saarbrücker Sicht. Beiträge der SaRDiS-Tagung zur Dialektsyntax (Zeitschrift Für Dialektologie und Linguistik - Beihefte 165), 187-219. Stuttgart: Franz Steiner.
Lenz, Alexandra N. 2017. SyHD-atlas: „Dativpassiv” (kriegen-Passiv). SyHD-atlas. http://www.syhd.info/apps/atlas/\#dativpassiv-kriegen-passiv (7 December, 2017). Lenz, Alexandra N. 2018a. Syntaktische Variation aus areallinguistischer Perspektive. In Angelika Wöllstein, Peter Gallmann, Mechthild Habermann \& Manfred Krifka (eds.), Grammatiktheorie und Empirie in der germanistischen Linguistik (Germanistische Sprachwissenschaft um 2020), vol. 1, 241-277. Berlin \& Boston: de Gruyter.

Lenz, Alexandra N. 2018b. The special research programme "German in Austria. Variation-contact-perception.” In Ulrich Ammon \& Marcella Costa (eds.), Sprachwahl im Tourismus-mit Schwerpunkt Europa. Language choice in tourism-Focus on Europe. Choix de langues dans le tourisme-focus sur l'Europe (Sociolinguistica 32), 269-277. Berlin \& Boston: de Gruyter.

Lenz, Alexandra N., Timo Ahlers \& Martina Werner. 2015. Zur Dynamik bairischer Dialektsyntax - eine Pilotstudie. Zeitschrift für Dialektologie und Linguistik LXXXI/1. 1-33.

Merkle, Ludwig. 1975. Bairische Grammatik. München: Heimeran.

Molnárfi, László. 1998. Kasusstrukturalität und struktureller Kasus - zur Lage des Dativs im heutigen Deutsch. Linguistische Berichte 176. 535-580.

Patocka, Franz. 1989. Dialektsyntax und Syntaxgeografie. Möglichkeiten und Grenzen. In Wolfgang Putschke, Werner Veith \& Peter Wiesinger (eds.), Dialektgeographie und Dialektologie: Günter Bellmann zum 60. Geburtstag von seinen Schülern und Freunden, 47-56. Marburg: Elwert.

Penner, Zvi. 1993. W-morphology in the COMP system of Bernese Swiss German and the licensing of empty operators in the prefield position. In Werner Abraham \& Josef Bayer (eds.), Dialektsyntax (Linguistische Berichte: Sonderheft 5), 201-212. Opladen: Westdeutscher Verlag.

Poletto, Cecilia. 2000. The higher functional field: Evidence from Northern Italian dialects (Oxford Studies in Comparative Syntax). New York: Oxford University Press.

Richner-Steiner, Janine. 2011. E ganz e liebi Frau. Zu den Stellungsvarianten in der adverbiell erweiterten Nominalphrase im Schweizerdeutschen. Eine dialektologische Untersuchung mit quantitativ-geographischem Fokus. Zürich: University of Zürich $\mathrm{PhD}$ thesis.

Schallert, Oliver. 2013. Syntaktische Auswertung von Wenkersätzen; eine Fallstudie anhand von Verbstellungsphänomenen in den bairischen (und alemannischen) Dialekten Österreichs. In Rüdiger Harnisch (ed.), Strömungen in der Entwicklung der Dialekte und ihrer Erforschung: Beiträge zur 11. Bayerisch-Österreichischen Dialektologentagung in Passau, September 2010, 208-233. Regensburg: edition vulpes.

Schallert, Oliver. 2014. Zur Syntax der Ersatzinfinitivkonstruktion: Typologie und Variation. Tübingen: Stauffenburg.

Schallert, Oliver, Alexander Dröge \& Jeffrey Pheiff. accepted. Doubly-filled COMPs in Dutch and German: A bottom-up approach. Linguistics.

Schiepek, Josef. 1899. Der Satzbau der Egerländer Mundart, vol. 1. Prag: Verlag des Vereines für Geschichte der Deutschen in Böhmen.

Schiepek, Josef. 1908. Der Satzbau der Egerländer Mundart, vol. 2. Prag: Verlag des Vereines für Geschichte der Deutschen in Böhmen.

Seiler, Guido. 2005. Wie verlaufen syntaktische Isoglossen, und welche Konsequenzen sind daraus zu ziehen? In Eckhard Eggers, Jürgen Erich Schmidt \& Dieter Stellmacher (eds.), Moderne Dialekte-Neue Dialektologie, 313-341. Stuttgart: Franz Steiner.

Seiler, Guido. 2003. Präpositionale Dativmarkierung im Oberdeutschen (Zeitschrift für Dialektologie und Linguistik - Beihefte 124). Stuttgart: Franz Steiner.

Steiner, Janine. 2005._Also d'Susi wär e ganz e liebi Frau für de Markus!_Zur Verdoppelung des indefiniten Artikels in der adverbiell erweiterten Nominalphrase im Schweizerdeutschen. Linguistik Online 24(3). 115-134.

Strobel, Thomas \& Helmut Weiß. 2017. Möglichkeiten der Reduplikation des Indefinitartikels im Bairischen. In Alexandra N. Lenz (ed.), Bayerischösterreichische Varietäten zu Beginn des 21. Jahrhunderts-Dynamik, Struktur, Funktion (Zeitschrift Für Dialektologie und Linguistik Beihefte 167), 71-88. Stuttgart: Franz Steiner.

Tatzreiter, Herbert. 1989. Zur Zweidimensionalität in der Spracherhebung (Mit einem bairisch-steirischen Beispiel). In Wolfgang Putschke, Werner Veith \& Peter Wiesinger (eds.), Dialektgeographie und dialektologie: Günter Bellmann zum 60. Geburtstag von seinen Schülern und Freunden, 164177. Marburg: Elwert. 
Teuber, Oliver. 2005. Analytische verbformen im Deutschen: Syntax, semantik, grammatikalisierung (Germanistische Linguistik: Monographien 18). Hildesheim, Zürich: Olms.

Weiß, Helmut. 1998. Syntax des Bairischen: Studien zur Grammatik einer natürlichen Sprache (Linguistische Arbeiten 391). Tübingen: Niemeyer.

Weiß, Helmut. 2005. Inflected complementizers in continental West Germanic dialects. Zeitschrift für Dialektologie und Linguistik 72. 148-166.

Weiß, Helmut. 2017. SyHD-atlas: Doubly-filled COMP. SyHD-atlas. http://www.syhd.info/apps/atlas/\#doubly-filled-comp (5 December, 2017).
Weiß, Helmut \& Thomas Strobel. 2018. Neuere Entwicklungen in der Dialektsyntax. Linguistische Berichte 253. 3-35.

Wiesinger, Peter. 1983. Die Einteilung der deutschen Dialekte. In Werner Besch, Ulrich Knoop, Wolfgang Putschke \& Herbert E. Wiegand (eds.), Dialektologie: Ein Handbuch zur deutschen und allgemeinen Dialektforschung. Zweiter Halbband, 807-900. Berlin: de Gruyter.

Zehetner, Ludwig. 1985. Das bairische Dialektbuch. München: Beck.

Zifonun, Gisela, Ludger Hoffmann \& Bruno Strecker. 1997. Grammatik der deutschen Sprache (Schriften des Instituts für deutsche Sprache 7). Berlin: de Gruyter. 